\title{
Refining livestock mortality indicators: a systematic review
}

\section{[version 1; peer review: 3 approved]}

\author{
Johanna T. Wong, Ciara J. Vance, Andrew R. Peters (iD
}

Supporting Evidence-Based Interventions - Livestock, University of Edinburgh, Easter Bush, Midlothian, EH25 9RG, UK

V1 First published: 19 Apr 2021, 5:75

https://doi.org/10.12688/gatesopenres.13228.1

Latest published: 19 Apr 2021, 5:75

https://doi.org/10.12688/gatesopenres.13228.1

\section{Abstract}

Background: Livestock mortality impacts farmer livelihoods and household nutrition. Capturing trends in livestock mortality at localised or national levels is essential to planning, monitoring and evaluating interventions and programs aimed at decreasing mortality rates. However, livestock mortality data is disparate, and indicators used have not been standardised. This review aims to assess livestock mortality indicator definitions reported in literature, and define the ages where mortality has greatest impact.

Methods: A systematic review was conducted, limited to articles focussed on mortality of cattle, sheep and goats. Peer-reviewed articles in Web of Science until year 2020 were assessed for inclusion of age-based definitions for mortality indicators and data on age distribution of mortality. Indicator definitions for each species were collated and similar terms and age groups most targeted were compared. The cumulative distribution of age at mortality was compared across studies graphically where possible; otherwise, age patterns for mortality were collated.

Results: Most studies reported mortality risk rather than rate, and there was little agreement between indicator definitions used in the literature. The most common indicators reported were perinatal and neonatal mortality in cattle, and for perinatal, neonatal and preweaning mortality indicators for sheep and goats. Direct comparison of age distribution of mortality was only possible for cattle, which found that approximately $80 \%$ of all mortalities within the first 12 months had occurred by six months of age. A significant finding of the study is the variation in age groups for which mortality is reported, which impedes the comparison of mortality risk across studies, particularly for sheep and goats.

Conclusions: This study demonstrates the importance and value of standardising mortality risk indicators for general use, including a young stock mortality risk indicator measuring mortality in the highest risk period of birth to six months of age in cattle, sheep and goats.

\section{Open Peer Review}

\begin{tabular}{lccc}
\hline Approval Status & 1 & 2 & 3 \\
\hline version 1 & & & \\
19 Apr 2021 & view & view & view \\
\hline
\end{tabular}

1. Alasdair J.C. Cook ID, University of Surrey, Guildford, UK

2. Ishmael Festus Jaja (D), Risk and Vulnerability Science Centre, University of Fort Hare, Alice, South Africa

3. Julia Adriana Calderón Díaz (iD), Teagasc Animal and Grassland Research and Innovation Centre, Fermoy, Ireland Martyna Lagoda iD, Teagasc Animal and Grassland Research and Innovation Centre, Fermoy, Ireland

Any reports and responses or comments on the article can be found at the end of the article. 
Keywords

Livestock mortality, mortality rate, mortality risk, perinatal mortality,

neonatal mortality, young stock mortality.

This article is included in the AgriKnowledge

w Agriknowledge gateway.

\section{Corresponding author: Andrew R. Peters (andy.peters@ed.ac.uk)}

Author roles: Wong JT: Data Curation, Formal Analysis, Investigation, Methodology, Validation, Visualization, Writing - Original Draft Preparation, Writing - Review \& Editing; Vance CJ: Conceptualization, Investigation, Project Administration, Supervision, Writing - Review \& Editing; Peters AR: Conceptualization, Formal Analysis, Funding Acquisition, Investigation, Resources, Supervision, Writing - Review \& Editing

Competing interests: No competing interests were disclosed.

Grant information: This work was supported by the Bill and Melinda Gates Foundation [INV-009921].

The funders had no role in study design, data collection and analysis, decision to publish, or preparation of the manuscript.

Copyright: @ 2021 Wong JT et al. This is an open access article distributed under the terms of the Creative Commons Attribution License, which permits unrestricted use, distribution, and reproduction in any medium, provided the original work is properly cited.

How to cite this article: Wong JT, Vance CJ and Peters AR. Refining livestock mortality indicators: a systematic review [version 1; peer review: 3 approved] Gates Open Research 2021, 5:75 https://doi.org/10.12688/gatesopenres.13228.1

First published: 19 Apr 2021, 5:75 https://doi.org/10.12688/gatesopenres.13228.1 


\section{Introduction}

Approximately 1 billion poor people globally are dependent on livestock for their livelihoods (Ashley et al., 1999; FAO, 2009; Salmon et al., 2020). However, the benefits derived from livestock ownership, including income and household nutrition, are constrained by poor animal health and low productivity (Perry et al., 2002). The impact of livestock disease has been cited in many publications e. g. Perry et al. (2013), but the ability to monitor change is limited as the available data is contained in disparate publications and reports, usually from individual countries, and there are few longitudinal studies of disease prevalence and impact. Donors to international development projects are increasingly interested in being able to monitor change in a country's performance particularly in response to investment.

It has been recognised that there is a great disparity between the contribution that livestock make to agricultural GDP in many countries compared to relatively poor investment in development of the livestock sector (Perry et al., 2002). In recent years, the Bill and Melinda Gates Foundation (BMGF) have been major investors in the low- and middle-income country (LMIC) livestock sector, and in particular, in animal health. However, it has become clear that development in LMIC agro-economies is hampered by the lack of data which can be used to prioritise policy investment decisions. Indeed, Mr. Bill Gates has himself stated "Great science is helping to turn livestock into a pathway out of poverty for hundreds of millions of people...we have a lot of tools [such as] breeding, gene editing, vaccines...the lack of data makes us pretty uncertain about the right way to go" (W. Gates, Edinburgh, 2018). This constraint applies to national governments, non-governmental organisations (NGOs) and other donors.

In response to this, the University of Edinburgh's Supporting Evidence-Based Interventions (SEBI) program, which is funded by the BMGF, aims to improve livestock data collection, curation and utilisation across the sector. This will enable the livestock community to make better investments and smallholder livestock keepers to make better-informed decisions, ultimately driving sustainable transformation of the livestock sector as a whole. Under the scope of this work, one of the key animal health indicators that SEBI will monitor on behalf of the BMGF is "livestock mortality rate", currently defined as the total cumulative number of livestock deaths over the approximate average number of animals in the herd. The BMGF has set a target for SEBI to investigate interventions that can decrease livestock mortality by $10-15 \%$ over a 10 -year period in their priority countries of Ethiopia, Nigeria and Tanzania. If such mortality reductions are achievable, this provides a significant opportunity to increase livestock productivity and in turn improve the livelihoods of smallholder farmers. To explore the feasibility of achieving this target, SEBI has been compiling evidence on current livestock mortality rates, causes, and possible interventions that may be able to achieve a significant mortality rate reduction. In addition, SEBI also aims to better define a set of indicators that the BMGF can use to monitor progress in their target areas of livestock health and productivity.

This review seeks to clarify the definition of "livestock mortality rate" in ruminants by first examining the rationale behind the use of mortality indicators, then exploring what definitions are currently used in the field, and in which age groups mortality has the greatest impact. The results of this review are then used to inform the selection of the best definition of mortality rate as an indicator to monitor development in animal health.

\section{Rationale behind use of mortality indicators}

Use in human health. Mortality rates are used extensively in human health literature to monitor progress in human development. However, mortality rates are usually qualified by factors such as age, life stage, or cause. To illustrate this, Table 1 shows the definitions of selected Sustainable Development Goal (SDG) targets and indicators measuring mortality rates from SDG 3: "Ensure healthy lives and promote well-being for all at all ages" (UNSD, 2020a; UNSD, 2020b). The specificity of each mortality indicator allows comparison across time and space. Changes in trend can also be traced back to a relatively discrete number of factors for each indicator, and therefore drive targeted research, programs and interventions.

Although only encompassing narrow age groups, neonatal, infant and under-five mortality rates are often used as barometers for overall population health (UNSD, 2020a; WHO, 2021). Reidpath \& Allotey (2003) examined the ability of infant mortality rate (IMR), defined as the number of deaths in children under 1 year of age per 1000 live births in the same year, to represent whole population health compared to the more comprehensive measure of disability-adjusted life expectancy (DALE), which accounts for mortality as well as non-fatal morbidity. The analysis found a strong, linear correlation between IMR and DALE, showing that IMR is a feasible and useful indicator of whole population health. Reidpath \& Allotey (2003) also discussed the difference in resources required to collect data for each indicator, highlighting that the simpler IMR was more feasible to monitor in resource-poor countries.

This is important considering the resources that are required to collect a broad set of data to construct complex indicators, compared to the resource limitations often faced in LMICs.

Use in livestock health. Livestock fulfil multiple roles in various parts of the world; however, their primary roles are generally for income generation, food, and employment (Herrero et al., 2013; Salmon et al., 2020). This focus on production marks a significant difference in perspective between human and animal health and means that indicators that measure progress in humans may not be directly transferrable to livestock. In addition, the mixture of public and private interests in livestock production complicates and often limits the availability of public resources for animal health. Practically, 
Table 1. Selected SDG indicators from SDG 3 that measure human mortality rates (UNSD, 2020a; UNSD, 2020b).

\begin{tabular}{l|l|l}
\hline Target & Indicator & Definition
\end{tabular}

3.1: By 2030, reduce the global maternal mortality ratio to less than 70 per 100,000 live births.

3.1.1: Maternal mortality ratio

3.2.1: Under-five mortality
rate

3.2: By 2030, end preventable deaths of newborns and children under 5 years of age, with all countries aiming to reduce neonatal mortality to at least as low as 12 per 1,000 live births and under-5 mortality to at least as low as 25 per 1,000 live births.

3.4: By 2030, reduce by one third premature mortality from noncommunicable diseases through prevention and treatment and promote mental health and well-being.

3.2.2: Neonatal mortality rate

The annual number of maternal deaths from any cause related to or aggravated by pregnancy or its management (excluding accidental or incidental causes) during pregnancy and childbirth or within 42 days of termination of pregnancy, irrespective of the duration and site of the pregnancy, per 100,000 live births, for a specified year.

The probability (expressed as a rate per 1,000 live births) of a child born in a specified year or period dying before reaching the age of five if subject to current age-specific mortality rates.

The probability that a child born in a specific year or period will die during the first 28 completed days of life if subject to current age-specific mortality rates, expressed per 1,000 live births.

Neonatal deaths may be subdivided into early neonatal deaths (first seven days of life), and late neonatal deaths (after 7th day but before 28th completed day of life).

The percent of 30-year-old people who would die before

3.4.1: Mortality rate attributed to cardiovascular disease, cancer, diabetes, or chronic respiratory disease

3.9.1: Mortality rate attributed to household and ambient air pollution.

3.9.2: Mortality rate attributed to unsafe water unsafe sanitation and lack of hygiene

3.9.3: Mortality rate attributed to unintentional poisoning their 70th birthday from cardiovascular diseases, cancer, diabetes, or chronic respiratory diseases, under the assumption that the experienced mortality rate does not change over time, excluding other causes of death such as accidents or HIV/AIDS. This indicator is calculated using the life table method.

The mortality attributable to the joint effects of household and ambient air pollution and can be expressed as per 100,000 population for any given population group (e.g. children under 5 years of age).

The number of deaths from unsafe water, unsafe sanitation and lack of hygiene in a year per 100,000 population.

hazardous chemicals and air, water and soil pollution and contamination by livestock keepers may be comparatively greater for those whose livestock fulfil several purposes, as is the case in many LMICs.

A suite of mortality indicators available for use in animals, as described by Thrusfield \& Christley (2018), are presented in Table 2. Issues with the current definitions are immediately evident: the authors do not define the age for which calf/lamb/kid or neonatal mortality rates apply, as "there is not a universal agreement on the age at which animals cease to be neonates in veterinary medicine". With this range of indicators and a lack of consensus on age groupings, it is important to gain a better understanding of what the term "mortality rate" actually means in a practical sense, particularly when referencing specific age groups. To this end, a literature search loss of stock represents a loss of wealth, livelihood, nutrition, genetic material, and a waste of investment, whether financial or through labour. The magnitude of lost value experienced 
Table 2. Mortality indicators used in veterinary epidemiology (Thrusfield \& Christley, 2018).

\begin{tabular}{|c|c|c|}
\hline Indicator & Numerator & Denominator \\
\hline Cumulative mortality & $\begin{array}{l}\text { Number of individuals that die during a } \\
\text { particular period }\end{array}$ & $\begin{array}{l}\text { Number of individuals in the population at } \\
\text { the beginning of that period }\end{array}$ \\
\hline Mortality rate or mortality density & $\begin{array}{l}\text { Number of deaths due to a disease that occurs } \\
\text { in a population during a particular period of } \\
\text { time }\end{array}$ & $\begin{array}{l}\text { The sum, over all individuals, of the length } \\
\text { of time at risk of dying }\end{array}$ \\
\hline $\begin{array}{l}\text { Death rate or crude mortality } \\
\text { rate }^{a}\end{array}$ & $\begin{array}{l}\text { The total mortality rate for all diseases (rather } \\
\text { than just one) }\end{array}$ & $\begin{array}{l}\text { The sum, over all individuals, of the length } \\
\text { of time at risk of dying }\end{array}$ \\
\hline Case fatality & Number of deaths & Number of diseased animals \\
\hline Crude death rate (in $10^{\mathrm{b}}$ animals) & Number of deaths occurring & Average population \\
\hline $\begin{array}{l}\text { Age-specific death rate (in } 10^{b} \\
\text { animals) }\end{array}$ & $\begin{array}{l}\text { Number of deaths among animals in a specified } \\
\text { age group }\end{array}$ & $\begin{array}{l}\text { Average number in the specified age } \\
\text { group }\end{array}$ \\
\hline $\begin{array}{l}\text { Calf/lamb/kid mortality rate (in } \\
10^{b} \text { animals) }\end{array}$ & Number of deaths under a specified age & Number of live births \\
\hline $\begin{array}{l}\text { Neonatal mortality rate (in } 10^{\mathrm{b}} \\
\text { animals) }\end{array}$ & Number of deaths under a specified age & Number of live births \\
\hline Foetal death rate (in $10^{\mathrm{b}}$ animals) & Number of foetal deaths & Number of live births plus foetal deaths \\
\hline $\begin{array}{l}\text { Cause-specific death rate (in } 10^{\mathrm{b}} \\
\text { animals) }\end{array}$ & Number of deaths from a specified cause & Average population \\
\hline
\end{tabular}

was performed with the aim to collate and review the terms that are most frequently used within the livestock farmer, professional and scientific research communities, and to review the age categories which have the highest incidence of mortality with a view to refining the current definition of "livestock mortality rate". This review is reported in line with the Preferred Reporting Items for Systematic Reviews and Meta-Analyses (PRISMA) (Wong, 2021).

\section{Methods}

\section{Eligibility criteria}

A preliminary search was performed in Google to collect commonly used terminology from a mixture of academic and professional publications. This search showed that indicators used to monitor mortality rates are often specific for age groups (especially young animals), defined time periods (e.g., annual, a study duration), or specific diseases (i.e., case fatality rates). Common terms encountered during this preliminary search contributed to the development of a search strategy (outlined in Table 3) to retrieve articles reporting on mortality rates and age at mortality in cattle (both dairy and beef production systems), sheep, and goats.

Inclusion criteria. Articles from all countries published between 1900 and 2020 were considered for inclusion. A wide date range was used due to the scoping nature of the indicator definition review, and to maximise the inclusion of data from LMICs. The search included peer-reviewed journal articles (original research, secondary data analysis and reviews for both mortality indicator definitions and age distribution of mortality, and method articles also for indicator definitions). Data from published research reports related to the selected journal articles were included if they expanded on or clarified definitions used in the article. For age distribution of mortality, articles studying interventions were only included if baseline data were reported, and only baseline data was considered for inclusion. To ensure all nuances in indicator definitions were captured, articles were only included in the indicator definition section if they were in English.

Exclusion criteria. For both studies, articles were excluded if their abstracts or full text papers were not available. For the indicator definition section, studies were excluded if the definitions were based on events such as ear-tagging or weaning rather than age group. For age distribution of mortality, articles that only reported on cause-specific mortality rates, or articles that presented experimental data in laboratory settings that did not reflect realities in the field were excluded.

An overview of the criteria used to identify literature relating to the two purposes of this review is presented in in Table 4 .

\section{Search}

Literature searches were then performed in Web of Science (core databases) in June 2020. An initial search for "mortality" in combination with the full series of additional search terms 


\section{Table 3. Initial Web of Science search terms and results.}

\begin{tabular}{|c|c|c|}
\hline Search stem & Additional search term & $\begin{array}{l}\text { Number of } \\
\text { results }\end{array}$ \\
\hline Mortality rate AND & $\begin{array}{l}\text { Cattle OR bovine OR calf OR sheep OR ovine OR lamb OR } \\
\text { goat* or caprine OR kid }\end{array}$ & 4305 \\
\hline \multirow{4}{*}{ Perinatal mortality AND } & Livestock & 17 \\
\hline & Cattle OR bovine OR dairy OR beef OR calf OR calv* & 287 \\
\hline & Sheep OR ovine OR lamb* & 252 \\
\hline & Goat* OR caprine OR kid OR kids & 38 \\
\hline \multirow{4}{*}{ Neonatal mortality AND } & Livestock & 50 \\
\hline & Cattle OR bovine OR dairy OR beef OR calf OR calv* & 667 \\
\hline & Sheep OR ovine OR lamb* & 394 \\
\hline & Goat* OR caprine OR kid OR kids & 129 \\
\hline \multirow{4}{*}{$\begin{array}{l}\text { (Pre-weaning OR preweaning OR pre } \\
\text { wean* mortality) AND }\end{array}$} & Livestock & 83 \\
\hline & Cattle OR bovine OR dairy OR beef OR calf OR calv* & 1,490 \\
\hline & Sheep OR ovine OR lamb* & 543 \\
\hline & Goat* OR caprine OR kid OR kids & 207 \\
\hline \multirow{4}{*}{$\begin{array}{l}\text { Young stock mortality OR youngstock } \\
\text { mortality AND }\end{array}$} & Livestock & 15 \\
\hline & Cattle OR bovine OR dairy OR beef OR calf OR calv* & 61 \\
\hline & Sheep OR ovine OR lamb* & 18 \\
\hline & Goat* OR caprine OR kid OR kids & 8 \\
\hline \multicolumn{2}{|l|}{ Total } & 8564 \\
\hline
\end{tabular}

The large number of results for cattle contrasts with the limited amount of literature available for goats.

\section{Table 4. Study selection criteria.}

\begin{tabular}{|c|c|c|}
\hline \multirow[t]{2}{*}{ Domain } & \multicolumn{2}{|l|}{ Criteria } \\
\hline & Definition of mortality rate & Age at mortality \\
\hline Date range & $1900-2020$ & $1900-2020$ \\
\hline $\begin{array}{l}\text { Geographical } \\
\text { scope }\end{array}$ & Global & Global \\
\hline Type & $\begin{array}{l}\text { Peer-reviewed journal article, including original research, } \\
\text { secondary data analysis, method articles and reviews }\end{array}$ & $\begin{array}{l}\text { Peer reviewed journal article, including original research, } \\
\text { secondary data analysis and reviews. }\end{array}$ \\
\hline Specific details & $\begin{array}{l}\text { Defined or reported on mortality rates for explicit age } \\
\text { groups, including those reporting on specific diseases. } \\
\text { Articles that defined mortality based on events, such as } \\
\text { ear-tagging or weaning, were excluded if the typical or } \\
\text { average age at these events were not reported. }\end{array}$ & $\begin{array}{l}\text { Reported incidence of all-cause mortality by age. Articles } \\
\text { that reported mortality rates within study cohorts but did } \\
\text { not aim specifically to monitor or explore mortality, or } \\
\text { articles citing published mortality rates as part of study } \\
\text { backgrounds were excluded. }\end{array}$ \\
\hline Exclusions & $\begin{array}{l}\text { Abstract unavailable } \\
\text { Full text unavailable }\end{array}$ & $\begin{array}{l}\text { Abstract unavailable } \\
\text { Full text unavailable } \\
\text { Cause-specific mortality rates } \\
\text { Data from laboratory-based settings that are unlikely to } \\
\text { be replicated in the field. }\end{array}$ \\
\hline Language & English only & $\begin{array}{l}\text { All languages as long as specific details on study design } \\
\text { and age at mortality were able to be translated using } \\
\text { Google Translate. }\end{array}$ \\
\hline
\end{tabular}


yielded too broad a range of results, many of which were not related to livestock production. The search strings were refined, and the specific search strings used are presented in Table 3. A Google Scholar literature search for "livestock mortality rate" was also performed to ensure as many articles were included, as well as inclusion of relevant articles found within reference lists.

\section{Study selection}

For all terms, article titles were reviewed for relevance to livestock mortality rates. Article abstracts for relevant titles were then reviewed by two authors (J. W. and A. P.) according to the selection criteria (Table 4) and articles selected for full-text review. Full-text articles were reviewed by J. W. and A. P., and disagreements on inclusion were resolved through discussion. Where multiple papers arose from the same research study, or where research groups used the same definition or presented the same information across multiple papers, only the most detailed publication was included.

\section{Data extraction}

Data were extracted into a piloted form in Microsoft Excel version 2102. Data extracted included: author/s, citation, country of origin and income group, species and breed, production system characteristics, whether the aim/objectives of study directly related to livestock mortality, study type, recruitment procedure, sample size, time span covered, mortality indicator name, indicator enumerator, indicator denominator, whether abortions, stillbirths or culling events were included, and age distribution of mortality events recorded.

\section{Data analysis}

For the study of mortality indicator definitions, definitions were grouped by species and age range, and studied for patterns or common age ranges to produce a narrative summary. Given the scoping nature of this section of the review, studies were not individually assessed for bias.

For the study on age distribution of mortality, studies were first grouped into age ranges studied. Where studies overlapped in age range coverage, mortality risk by calendar month (365.25 days/12) was calculated, and the cumulative mortality risk by age in months graphed for each study along with the average mortality risk and standard deviation across studies. These studies were assessed for bias using the Risk of Bias Tool for Prevalence Studies (Hoy et al., 2012). Where studies did not have commonalities in age range, the results were included in a narrative summary. These studies were not assessed for bias. All analysis was done in Excel version 2102.

This review was not registered in PROSPERO and did not require ethical approval.

\section{Results}

To give a general overview of the popularity of each term and the availability of literature for each species, the number of returns for each search is included in Table 3. In terms of species distribution of literature, it is evident that cattle account for the largest proportion of articles, followed by sheep, with goats having very poor representation. Results of the literature search are presented in Figure 1. The database search in Web of Science yielded 382 potentially relevant articles based on title, while 40 articles were identified through Google Scholar and article reference lists. Duplicates $(n=80)$ were removed, before 190 articles were excluded based on their abstracts. Of the 152 full-text articles assessed for eligibility, 85 articles were included in the review. As some articles both defined mortality rate based on age and reported on age distribution of mortality, 52 articles were included in the study on mortality rate indicator definitions, while 53 articles were included for the age distribution of mortality study.

\section{Defining "mortality rate"}

The literature search for "mortality rate" in cattle, sheep and goats mostly yielded articles focussed on mortality in calves, lambs and kids. Few articles defined specific age groups for older animals - general herd or flock mortality rates tended to be reported instead. For all species and age groups, the literature was divided into those studies reporting a true mortality rate, and those reporting mortality risk.

Mortality incidence rate versus mortality incidence risk. The Centres for Disease Control and Prevention (CDC) define mortality rate as a "measure of the frequency of occurrence of death in a defined population during a specified interval" (CDC, 2012). For livestock, movement of animals in and out of the herd, from mortality, sale, or slaughter, is common and makes quantifying the "population" as a denominator in the ratio, more complex than in static populations. The most accurate way to define a varying population is to calculate the number of animal-days-at-risk, thereby no longer counting animals as being at risk from the day they leave the population (Thrusfield \& Christley, 2018). Mortality incidence rate is often expressed per 100-animal-months or -years. However, crude mortality rates, more correctly known as mortality risk, are often used. These use estimates of the population, such as the number of animals counted or average herd/flock sizes, as a denominator and are accepted proxies. Mortality risk is commonly reported as "mortality rate" (Thrusfield \& Christley, 2018). Within the 52 included studies, $42(81 \%)$ reported mortality risk, four reported mortality rate $(8 \%)$, four studies reported both $(8 \%)$ and in two review articles, it was not always clear whether the included articles reported risk or rate.

Age ranges used to define mortality rate. For cattle, the literature search identified 30 articles that used 20 mortality indicators (Table 5). Geographically, the 30 articles spanned 18 countries, with two studies having a global coverage. Using World Bank Group classifications (World Bank Data Team, 2019), nine were from high-income countries (HICs), and nine were from LMICs.

Perinatal and neonatal mortality indicators were the most commonly reported. For perinatal mortality, though there was variation between authors on definitions, most included stillbirths and measured mortality between birth and up to 24 or 48 


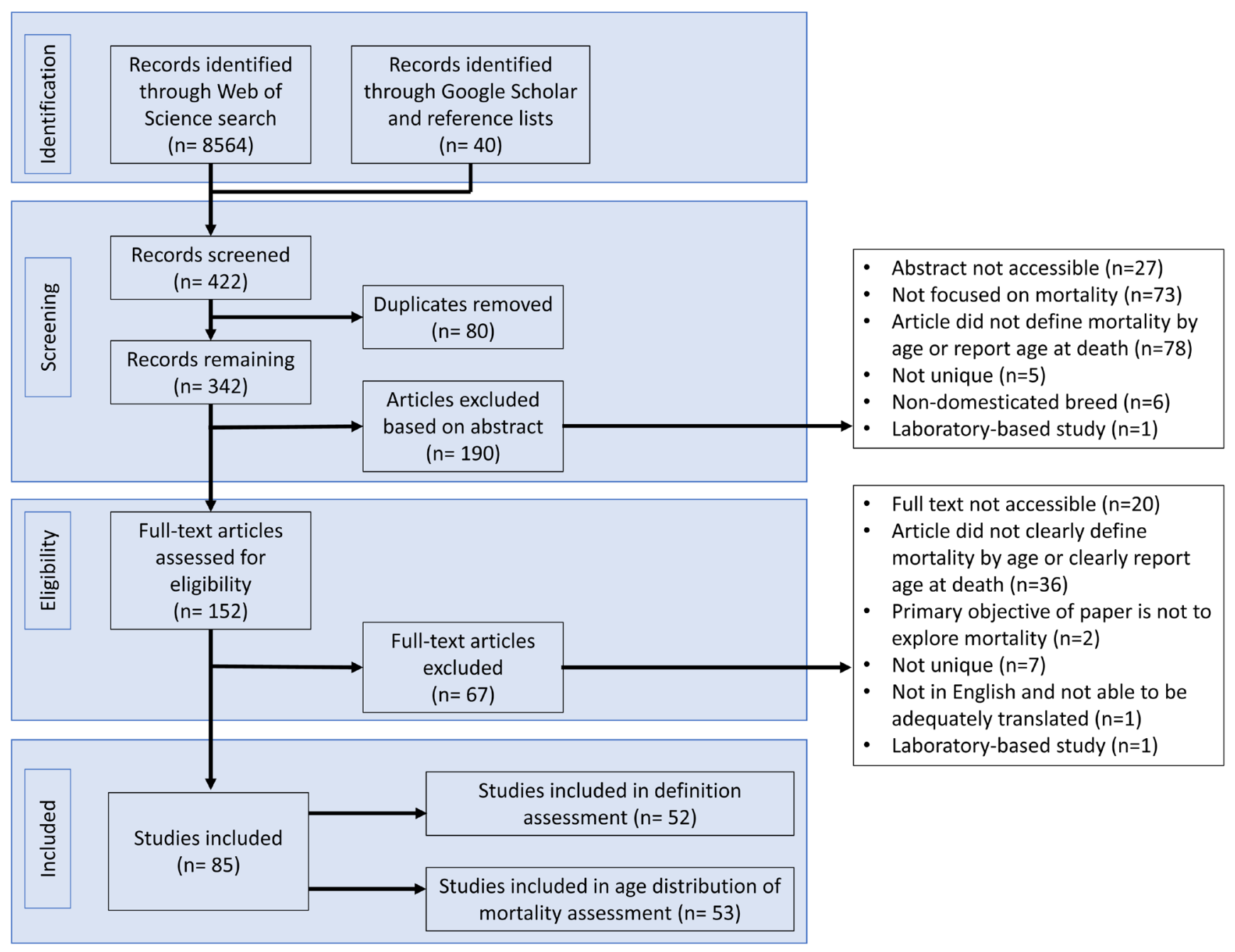

Figure 1. PRISMA flow chart for article screening and inclusion (adapted from Moher et al., 2009). Of the 8604 articles identified by the literature search, 422 titles were assessed as relevant. Eighty duplicates were removed, before 190 articles were excluded based on their abstract contents. Sixty-seven articles were excluded on assessing the full text, leaving 85 articles for inclusion into the study.

hours, while only a small number included abortions. There was similar variation in definitions for neonatal mortality, although from birth or 2-3 days through to one month of age was common. For older calves, there was a complete lack of consensus as to what age range indicators included.

For sheep, 20 studies were identified, reporting on 16 indicators of mortality (Table 6). These articles originated from 10 countries, including two HICs and eight LMICs and one article having a global scope. Perinatal, neonatal and pre-weaning mortality rates were most commonly reported. The definition of perinatal mortality varied greatly between authors, with indicators covering death between birth to 24 hours, 48 hours, seven days, and 14 days. There was a greater level of consensus for definitions of neonatal mortality, with most authors including mortalities from birth to 28 or 39 days of age. Pre-weaning mortality was most reported to be between birth to 90 days.

There was a dearth of articles reporting on mortality rates for goats. Only 11 articles were identified, from eight LMICs. These articles reported on 17 indicators (Table 7). Perinatal, neonatal and pre-weaning mortality rate definitions were reported by three authors each. Two of the three authors defined perinatal mortality as death within the first 48 hours of birth, while two authors also defined perinatal mortality as that occurring between 48 hours and one month of age. All three authors reporting on pre-weaning mortality defined this as mortality occurring 


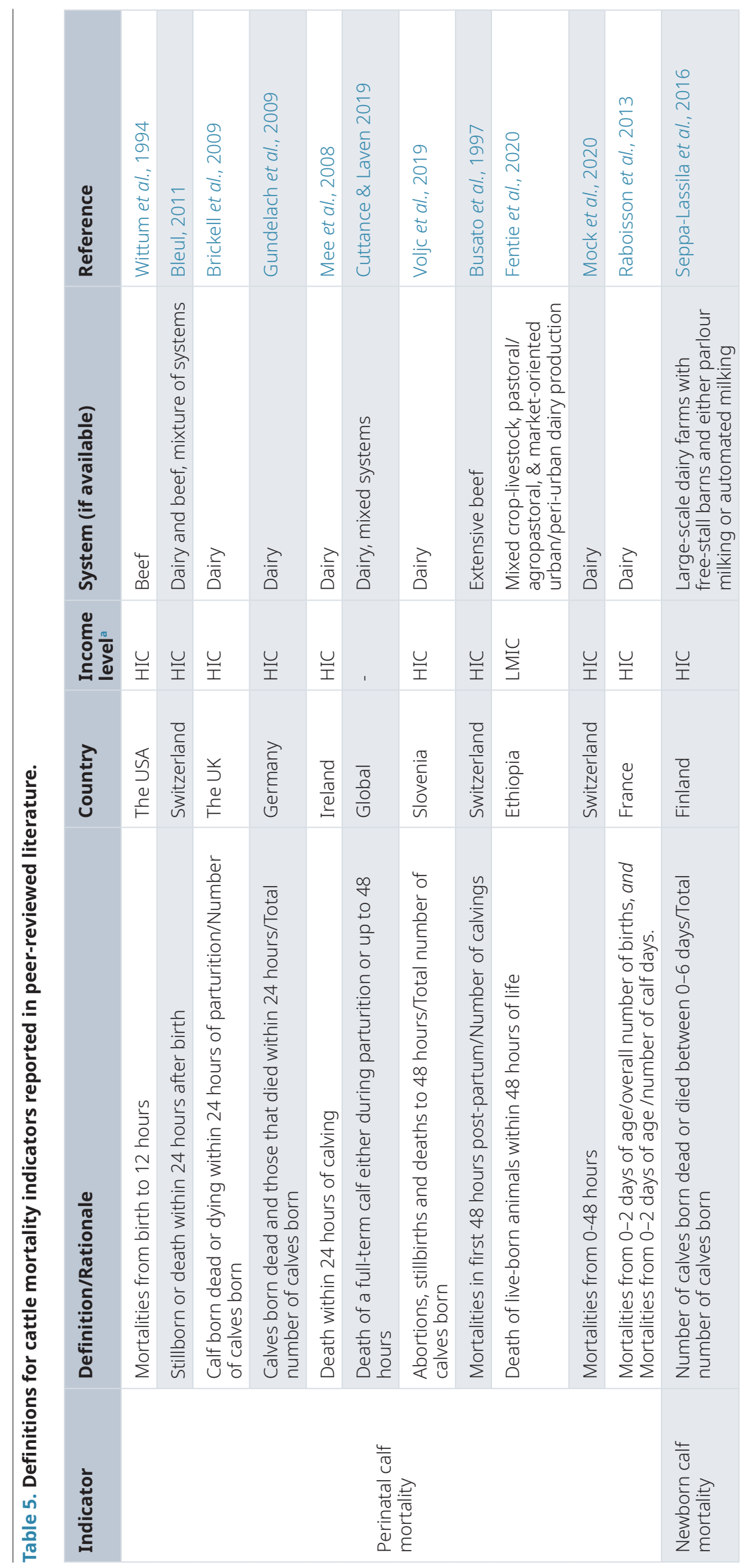




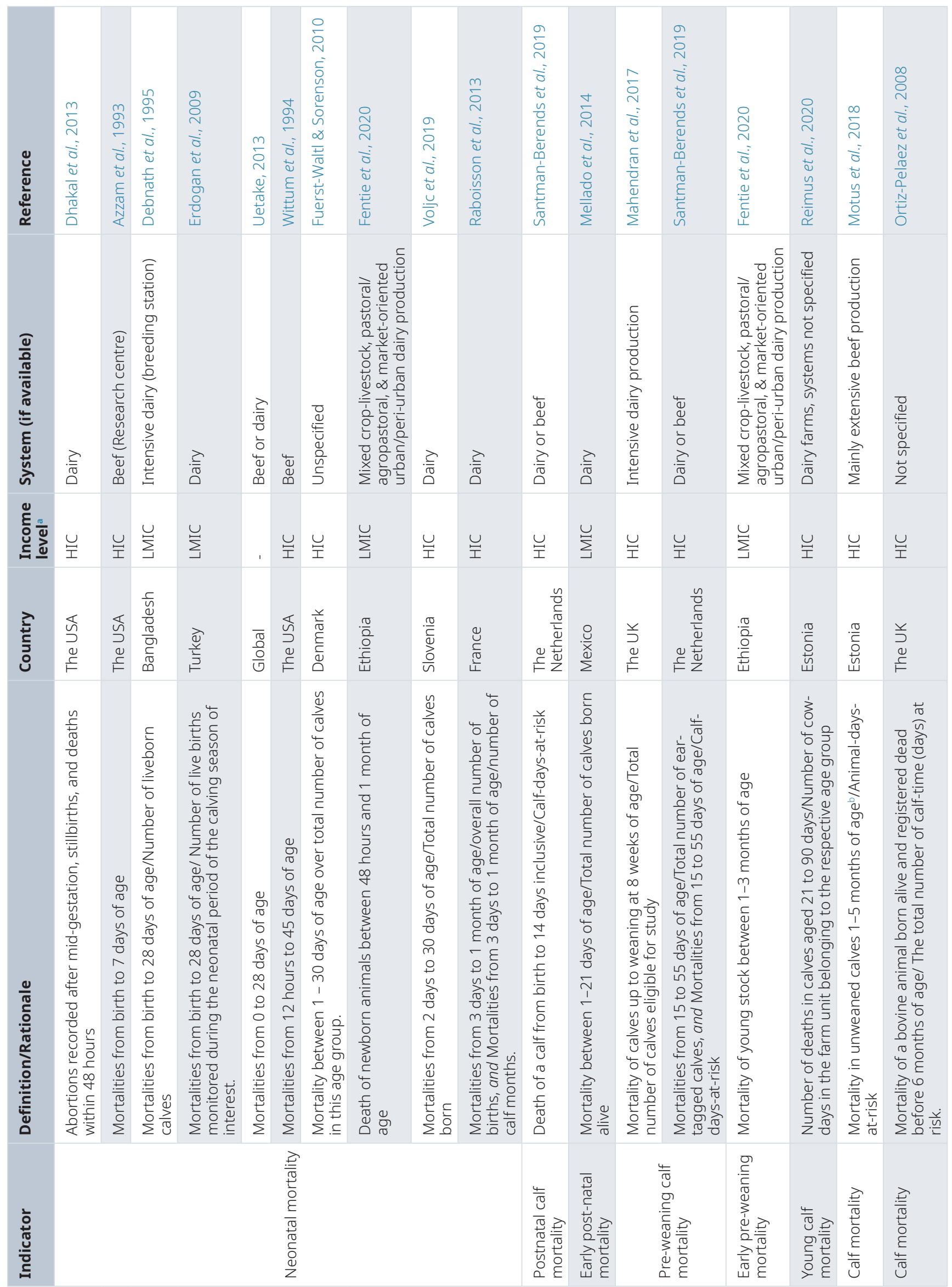




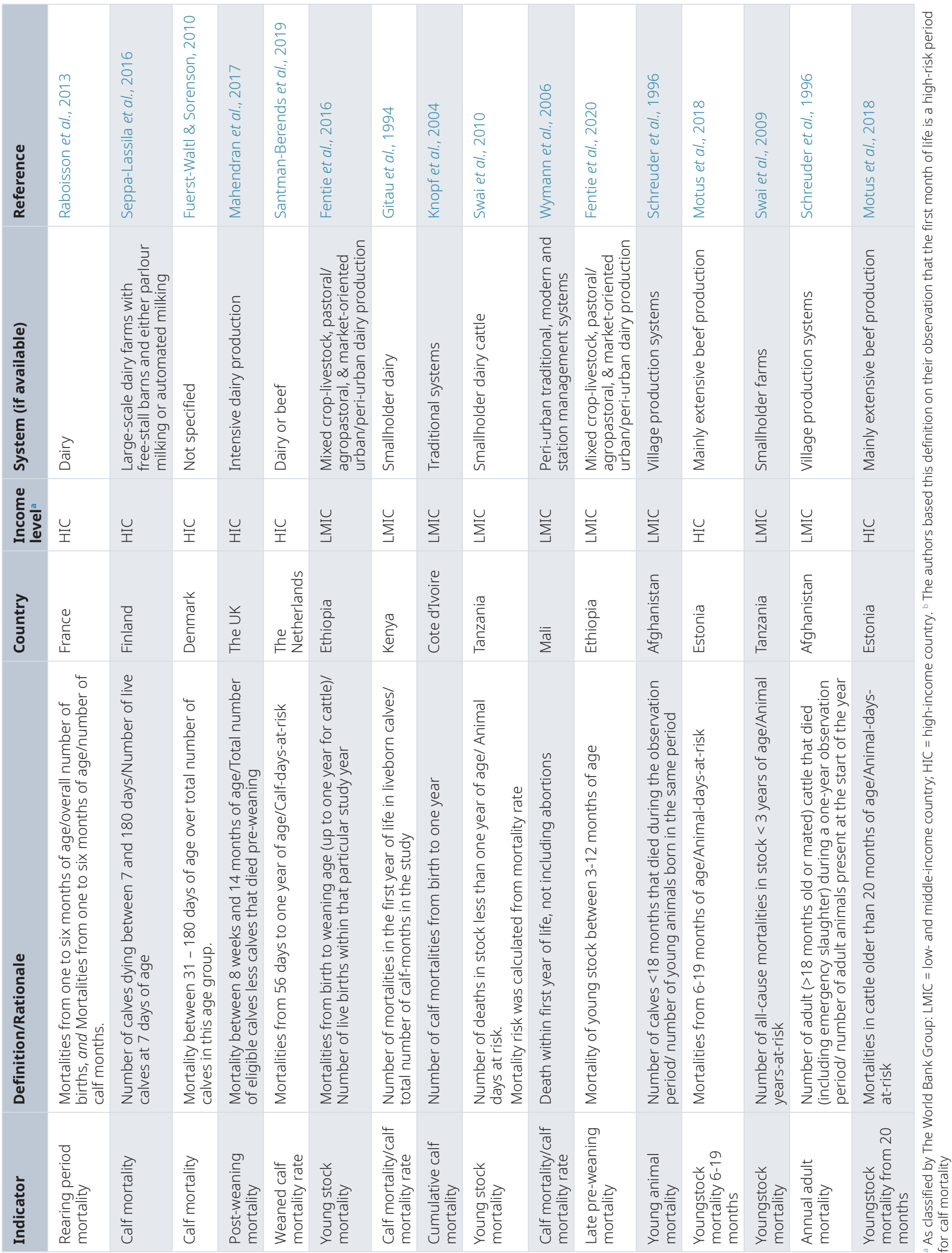




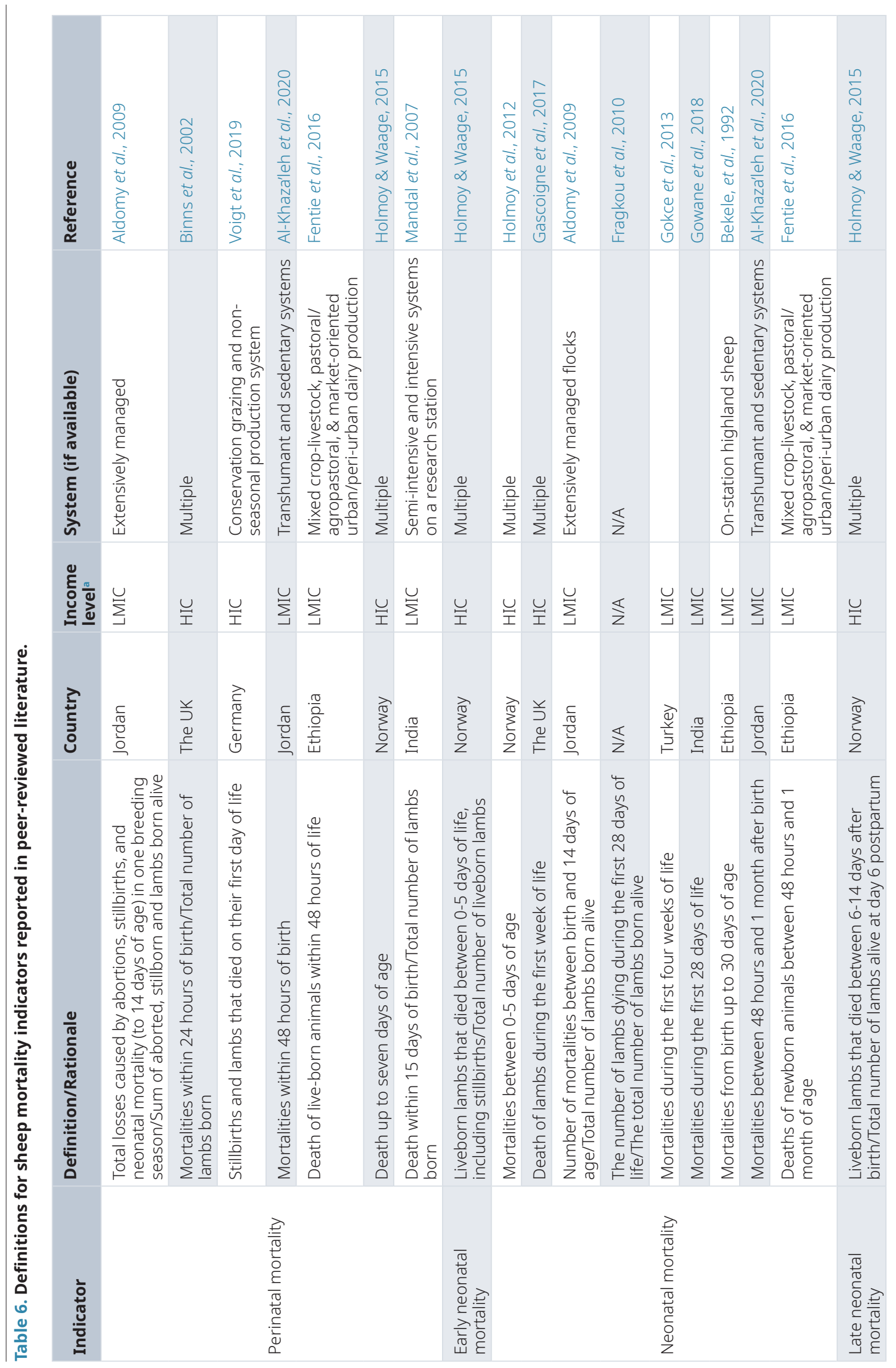




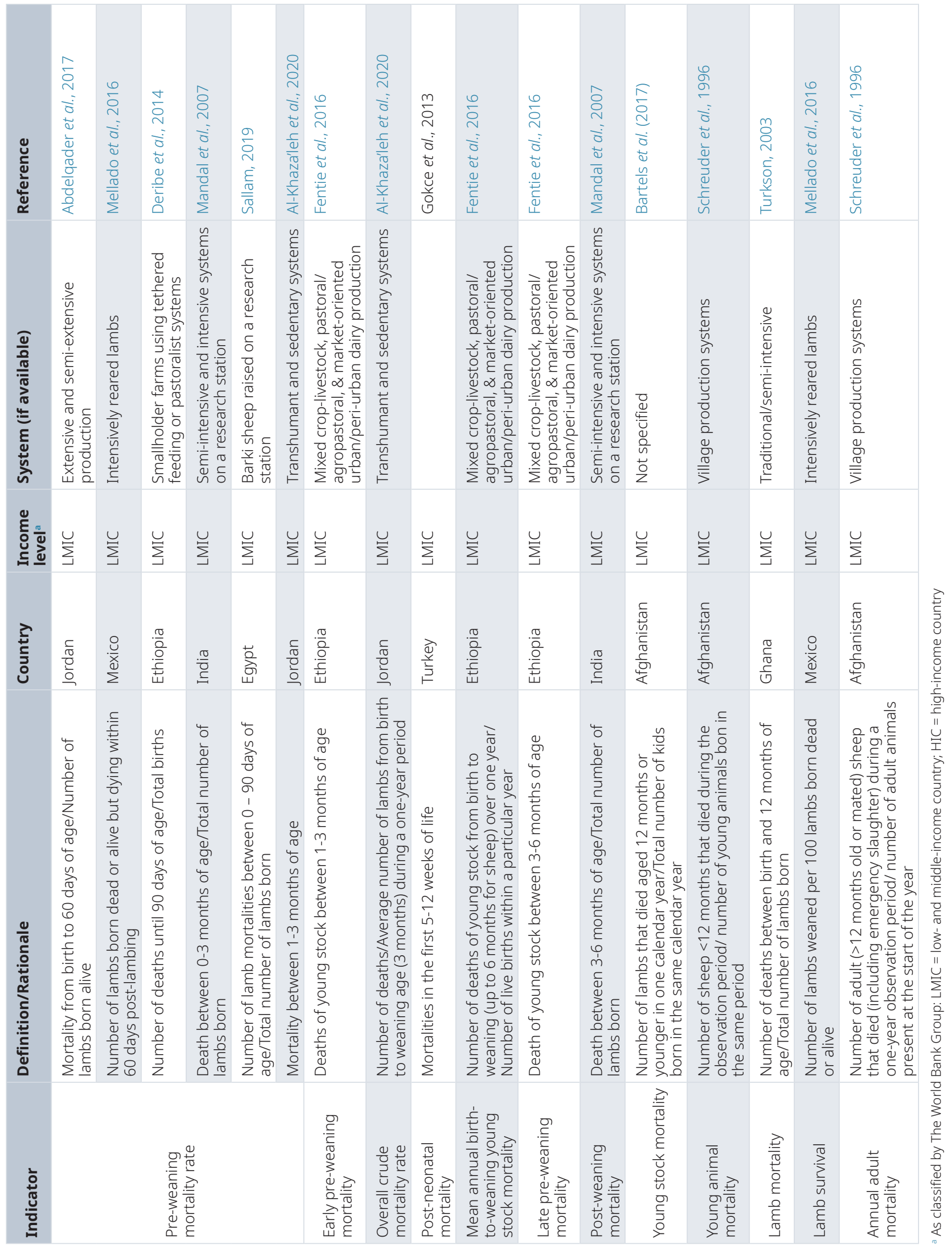




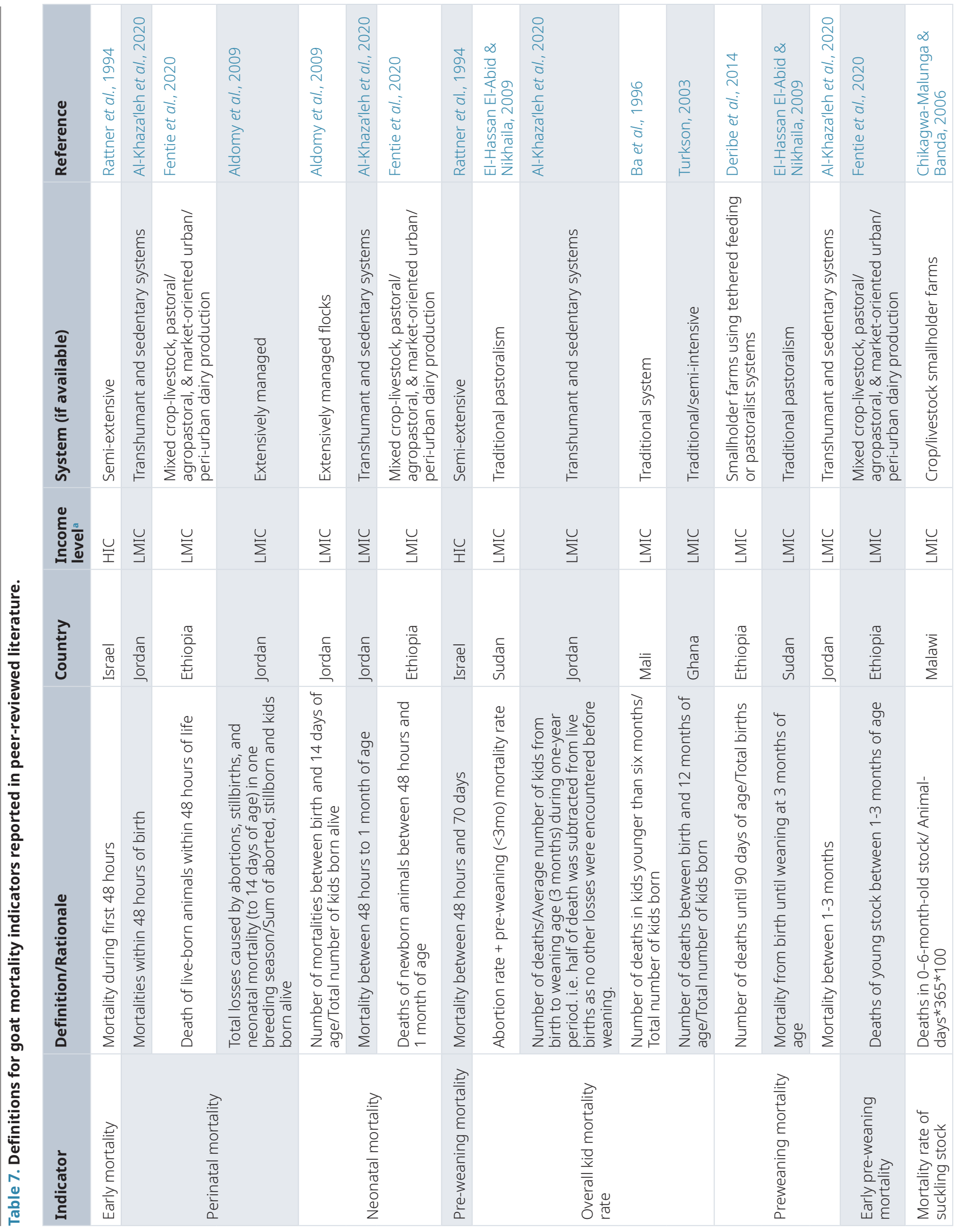




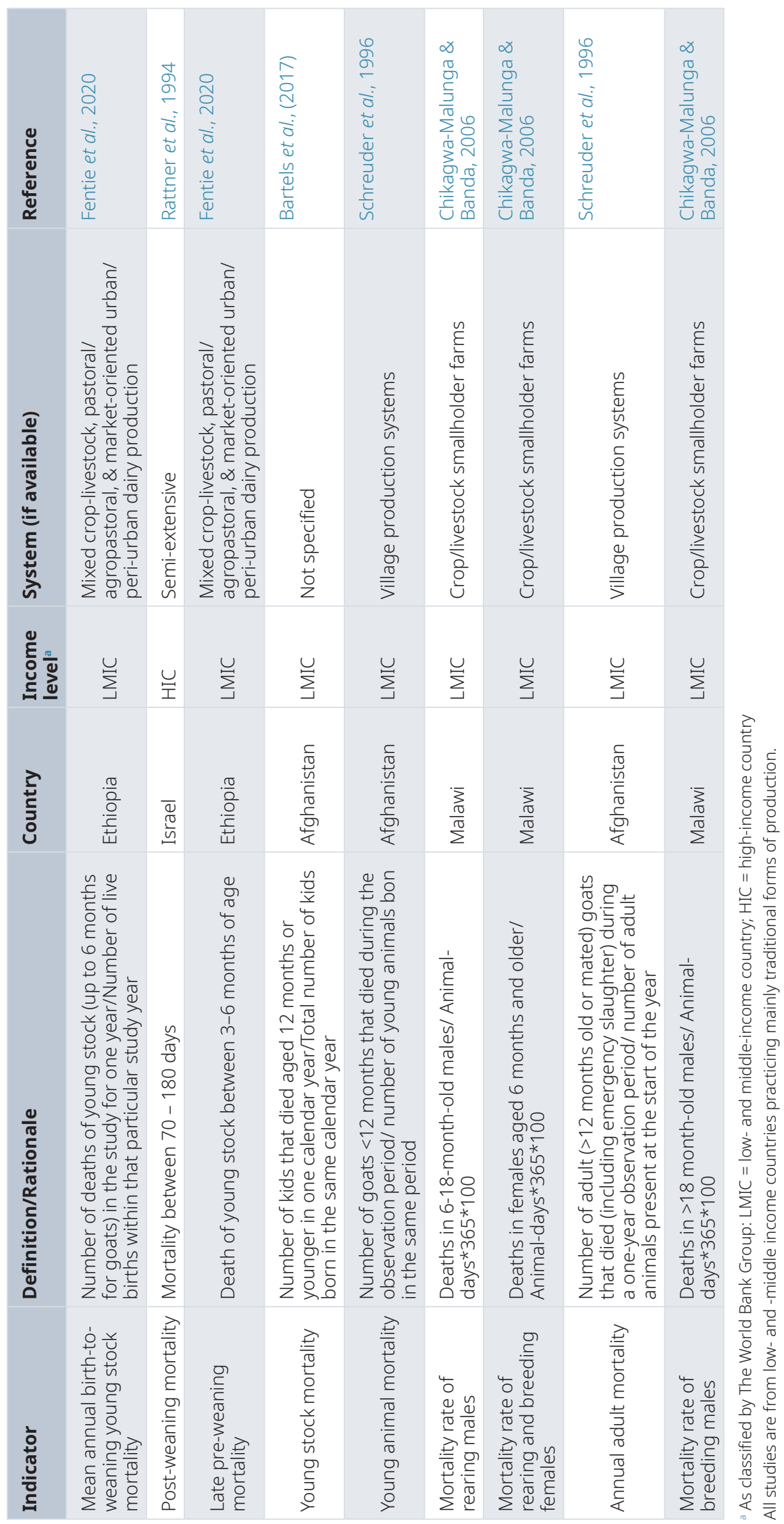


up to three months of age, although two authors measured this from birth, while one author measured this from one month of age.

A small number of studies arbitrarily divided the pre-weaning period into early and late stages of weaning, which differed greatly between authors. Papers that monitored mortality to weaning but did not specify when weaning typically occurred were excluded from the study. In the review article by Peeler \& Wanyangu (1998), the authors collated the weaning ages of lambs and kids reported in grey literature from Kenya. Across 12 studies, weaning age ranged between 120 - 224 days, with an average of 152 days and a standard deviation of 30 days, showing significant variation within weaning ages of production systems used in one country.

Few studies reported mortality rates specific to adult animals - most studies reporting adult mortality rates used crude flock or herd mortality risk, rather than an age-based indicator. The exception to this is in dairy cattle, where a small number of studies reported mortality by parity in dairy cattle (Traore \& Wilson, 1988; Upadhyay et al., 2014).

Across all indicators for cattle, there was no more consistency in definitions used within HIC/LMIC groupings than between the two income categories. The small number or absence of studies from HICs for sheep and goats precluded comparisons between different production income groups. For all species, age-defined indicators concentrated on the first few months of life.

\section{Age distribution of mortality}

While many articles discussing livestock mortality state that mortality rates are highest in younger age categories, few articles reported the distribution of mortality by age, particularly for animals older than one year. In cattle, 15 articles (Table 8) presented detailed tables of mortality by age, allowing crude comparison between studies. However, for sheep and goats, this information is scarce and spread across varying timeliness, making direct comparison difficult.

Mortality in adult cattle. Only four articles detailed age at mortality to at least three years of age. Data from these articles are presented in Figure 2. It is evident that mortality rises steeply in the first few months of life and begins to taper off by 12 months of age.

In addition to these studies reporting exact numbers, several papers presented cumulative mortality (or proportion of survival) over time graphically. In Mali, Traore \& Wilson (1988) showed that the proportion of cattle surviving dropped most steeply within the first three months of life, then declined at a fairly steady rate between 1-3 years, before becoming negligible between 3-4 years. Raboisson et al., 2013 showed that in three different dairy cattle breeds in France, heifer survival rates dropped most rapidly within the first 200 days of age, continuing at moderate rates between 200-400 days, before reaching a lower, stable rate between 400-1400 days. Zhang et al. (2019) reported on mortalities and involuntary culling rates in dairy calves and replacement heifers in China to 60 months of age. Frequency of mortality was highest in the <3-month age group, dropped dramatically between 3-6 months, then continued to drop until 60 months of age.

Mortality in young cattle. For cattle in the first 12-15 months of life, a total of 11 articles reported detailed mortality incidence risk over time. Study sizes, age groups for which data are presented and proportions of total mortality are included in Table 9. As demonstrated in the table, there is inconsistency in the age groupings used. Three studies reported mortality risk for each month, however, one study reported mortality for each 28-day period. Other studies reported mortalities for arbitrarily-determined age groups. To be able to compare and present this data graphically, figures were either averaged or consolidated to give monthly values, and this cumulative mortality risk for the first year of life is presented in Figure 3. For studies reporting mortality risk monthly, cumulative mortality rises sharply in the first $2-3$ months. In all but one study, $80 \%$ of mortalities that occur in the first year have occurred by six months of age.

Again, these observations are supported by many of the other studies that either did not report exact numbers over time or that presented data over a shorter period of time. Findings reported by authors included those where the largest proportion of deaths in cattle occurred intrapartum (Mock et al., 2020), in the first 48 hours (Busato et al., 1997; Raboisson et al., 2013), the first week (Gardner et al., 1990), first one- (Menzies et al., 1996), two- (Santman-Berends et al., 2019), or three- (Hyde et al., 2020) months of life.

For both extensively-managed beef cow-calf herds and large-scale, intensive dairy cattle production in Estonia, Motus et al. (2017) and Reimus et al. (2017) found that mortality rates were highest in female and male calves 0-3 months of age. For beef cattle, mortality rates dropped markedly after 3 months until 18 months of age in females, when they began to rise again, while mortality rates in male calves was more variable. In dairy cattle, for both sexes, mortality rates remained moderately high between 3-5 months, before dropping at 6 months of age. Data available for older age groups in female cattle show that mortality rates start to rise again at 24 months. Similarly, Selvan et al. (2019) reported mortality risk for two Zebu breeds and Zebu crossbreed calves under 6 months of age in India from longitudinal data from a research station. For the two Zebu breeds (Sahiwal and Tharparkar), mortality risk was highest in calves aged 0-1 month, whereas mortality risk was comparatively high for calves 0-1 month and 1-3 months of age for the crossbred calves. Norberg et al. (2013) studied mortality in Danish Jersey heifer calves aged 1-180 days and found that the risk of mortality was highest between days 1-14, moderate between days 15-30, and continued to decrease until 180 days of age. Slavik et al. (2009) found that in beef cattle herds in the Czech Republic, $62 \%$ of mortalities within the first six months occurred in the first week, with a further $28 \%$ occurring between one and four weeks of age. 


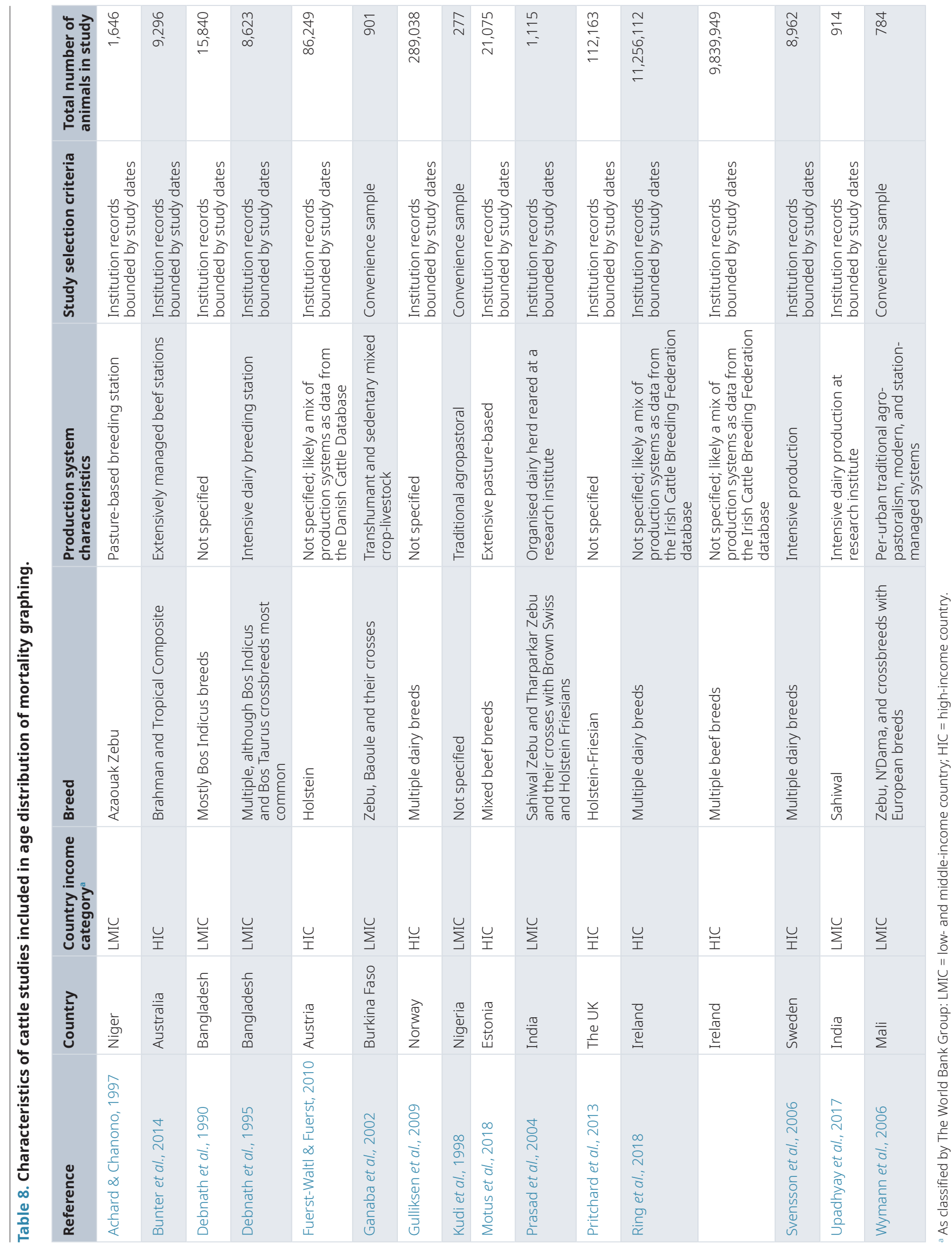




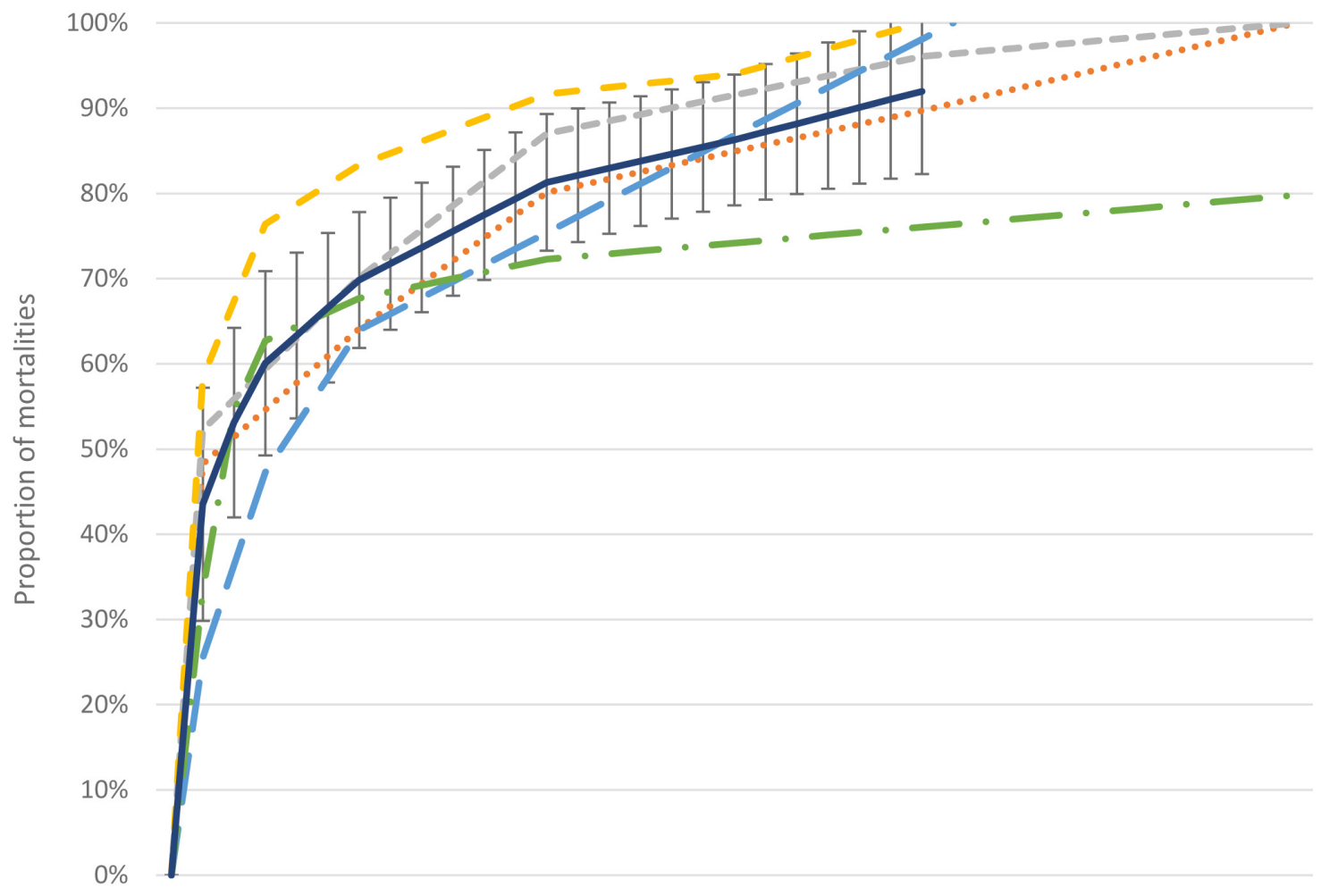

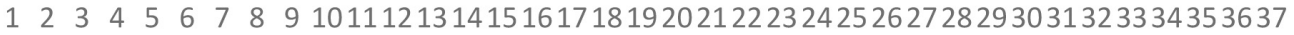

Age (months)

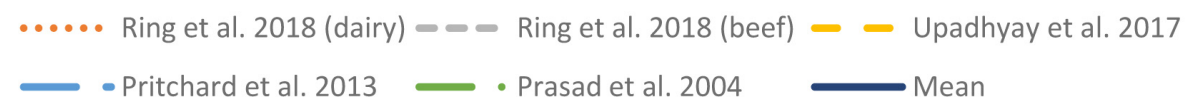

Figure 2. Cumulative mortality in cattle from birth to three years of age. Four included studies presented data on mortality distribution by age past 12 months of age. The black line shows the mean cumulative mortality with standard deviation bars.

In smallholder mixed crop-livestock systems in Kenya, Thumbi et al. (2013) found three periods where risk of cattle mortality was higher: the neonatal period, immediately after birth; between 150-190 days, when maternal antibody levels are waning; and towards one year of age, when calves are weaned. Knopf et al. (2014) reported that all deaths occurred in the first 210 days, while Pannwitz (2015) recorded the highest mortality rates in calves less than six months of age, then a decreased mortality rate between 6-24 months, and an uptick after 2 years of age.

In contrast to these findings, two authors, Debnath et al. (1990) (Figure 3) and Gitau et al. (1994) reported that no strong age patterns were seen in calf mortalities, while Seppa-Lassila et al. (2016) found that mean mortality risk in large-scale Finnish dairy cattle was $5.2 \pm 2.3 \%$ in calves $<7$ days, while the mortality risk in calves $7-180$ days was $5.7 \pm 6.2 \%$.
Risk of bias of included studies. For the 15 studies that published data sets showing age distribution of mortality in cattle, risk of bias was assessed using a tool refined by Hoy et al. (2012) (Table 10). All seven studies from HICs and five of the studies from LMICs utilised data from national registries, or research/breeding institutes, therefore random participant selection and non-response bias was unable to be assessed. It is possible that research or breeding station data may not be a true representation of realities in the field. Although some herds were managed as per the local normal, some stations had much more intensive management than would be found in surrounding areas. For the remaining three LMIC studies, these were conducted in the field using convenience sampling, based on farms being in accessible locations, being the site of previous studies, and willingness to participate by farmers. Convenience sampling may select participants who have a greater interest in the health and welfare of their cattle and therefore may employ 


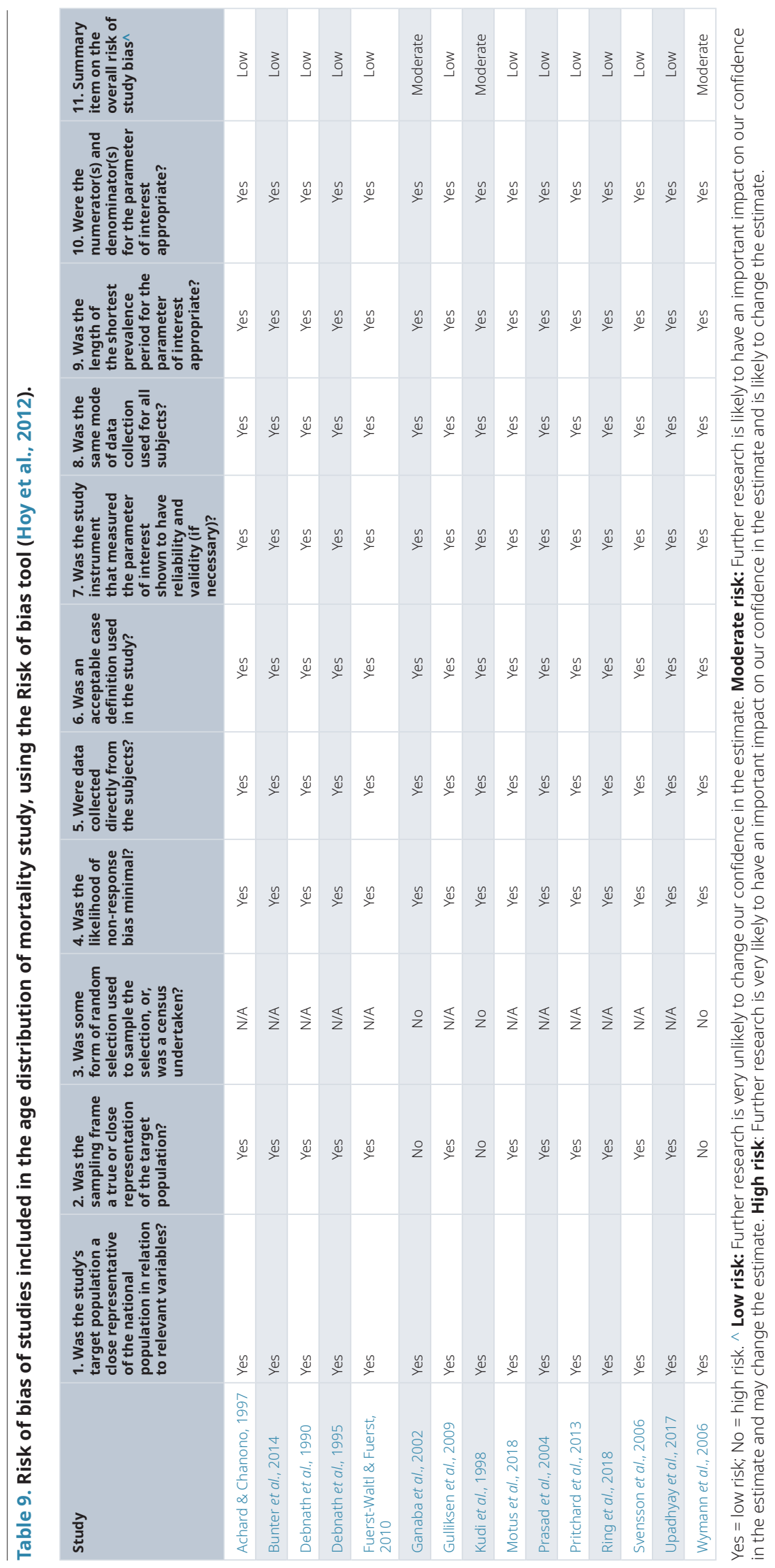




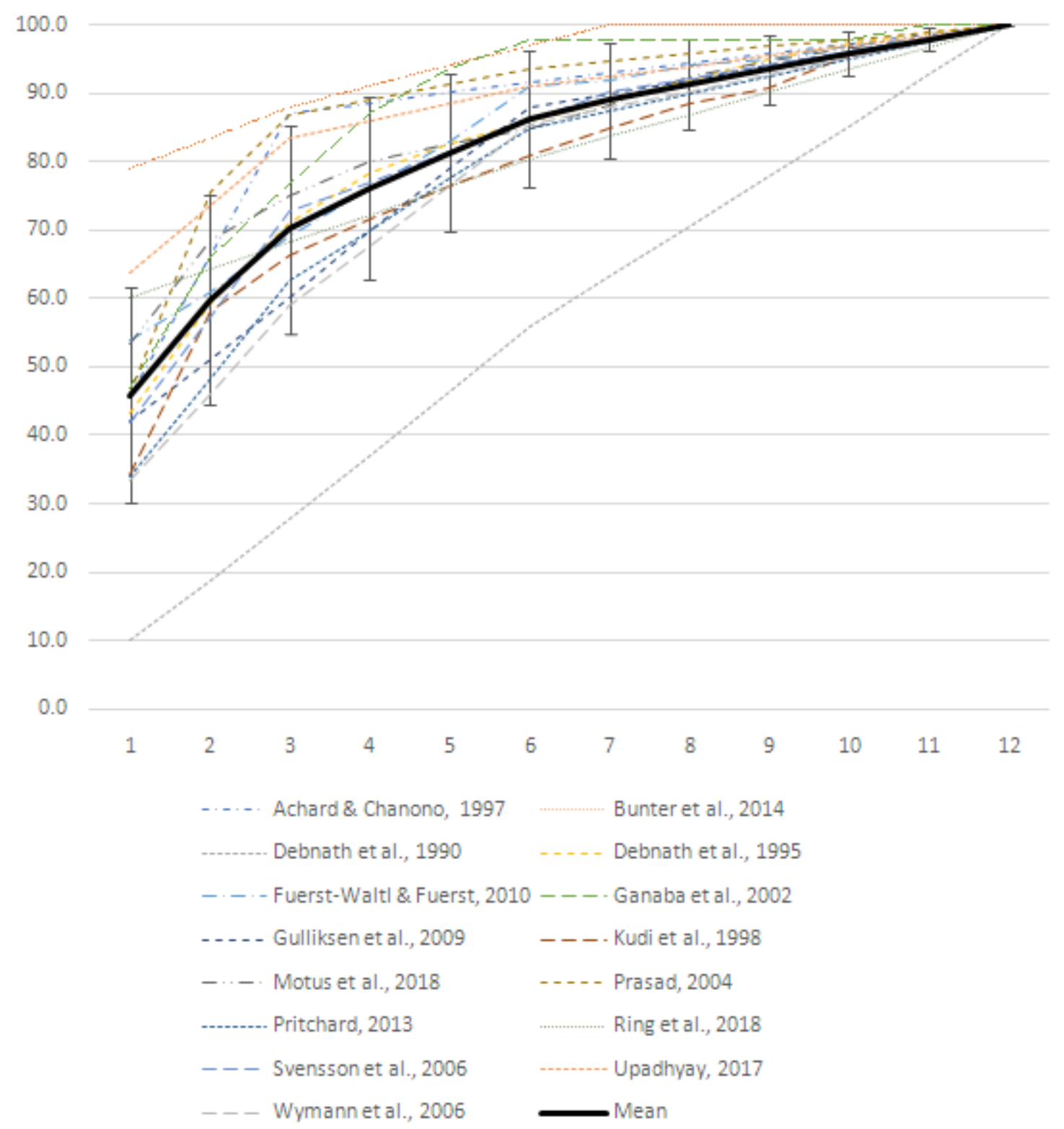

Figure 3. Cumulative mortality in calves between $\mathbf{0}$ - $\mathbf{1 2}$ months of age. This graph shows includes 15 studies reporting mortality distribution by age for at least the 12 months of age. The black line shows the mean cumulative mortality with standard deviation bars. On average, $86 \%$ of mortalities in the first 12 months had already occurred by six months of age.

better management practices, or who have better access to veterinary advice or treatments. Overall, the risk of bias in studies originating from HICs was assessed to be low, and moderate - though difficult to avoid due to constraints on how research can be undertaken - in studies originating from LMICs. Other types of bias, such as reporting bias, were not reported by studies and could not be assessed.

Mortality by age in small ruminants. For both sheep and goats, the variation in the time periods covered by different studies was too great to allow direct comparisons. In sheep, two papers noted that stillbirth and perinatal mortality rates were higher than at any age (Holmoy \& Waage, 2015); Voigt et al., 2019), while other authors report the largest proportion of mortalities occurred within 24 hours of birth (Binns et al., 2002), or within first week (Gokce \& Erdogan, 2009; Gokce et al., 2013; Khan et al., 2006). Holmoy et al. (2017) reported that $80 \%$ of neonatal lamb mortalities occurred within the first two days of life. Sallam (2019) found that average mortality risk for Barki sheep reared at a research station in Egypt was $4.6 \%$ for 


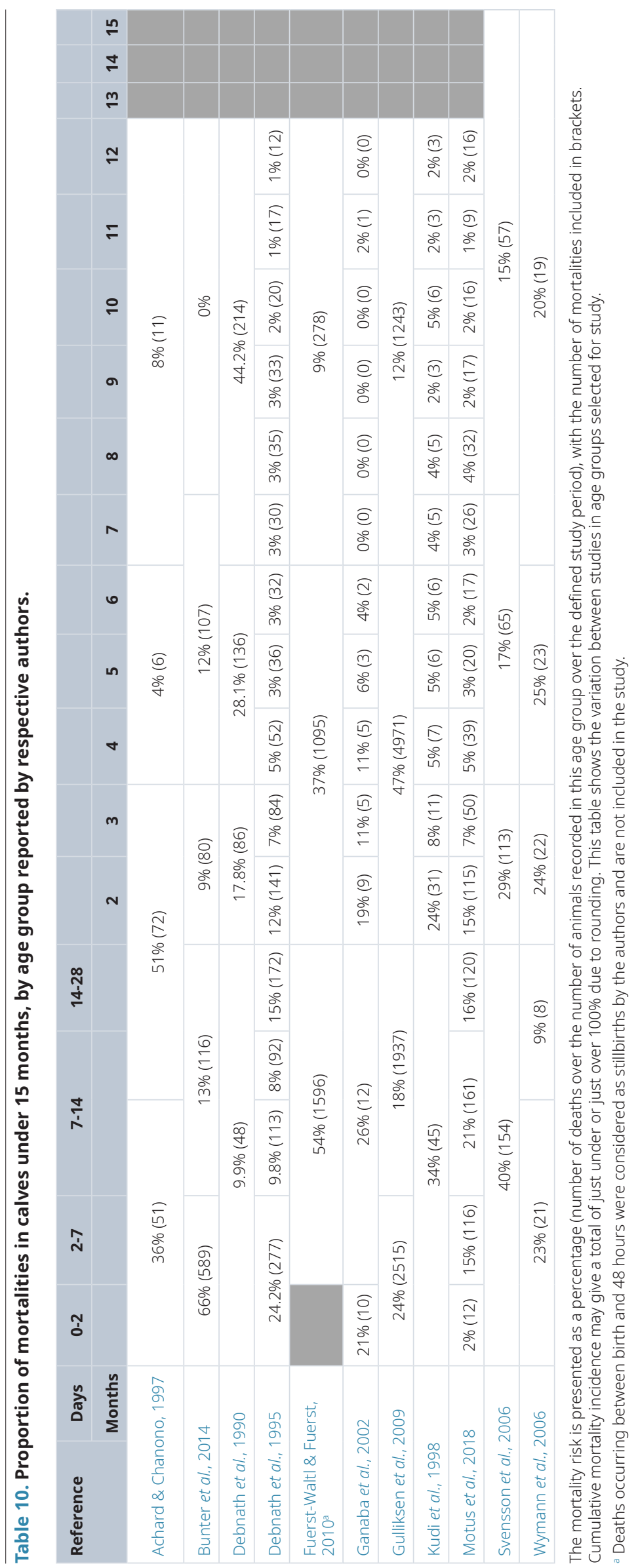


lambs 0-3 days of age, $5.4 \%$ for lambs 4-60 days of age, and $2.2 \%$ for lambs 61-90 days of age. Turkson (2003) found that for lambs from birth to 12 months of age, $75.6 \%$ of the mortalities occurred between 0-3 months, compared to $24.4 \%$ occurring between 4-12 months of age. In India, Mandal et al. (2007) reported that mortalities of Muzaffarnagari sheep reared in a research institute were highest in lambs under six months of age. Mortality risk for lambs from 0-3 months of age was $7.5 \%$ (with $64 \%$ of deaths occurring within 15 days of birth), decreasing to $2.7 \%$ from 3-6 months of age, $1.6 \%$ from 6-9 months of age, and 1.2\% from 9-12 months of age (Mandal et al., 2007). In Jordan, Abdelqader et al. (2017) found that $63.5 \%$ of pre-weaning (from birth to 60 days) lamb mortalities occurred within the first seven days of life. In semi-migratory and village sheep production systems in Iran, Vatankhah \& Talebi (2009) found that mortality risk was $6.14 \%, 12.76 \%$, $3.36 \%$ and $0.69 \%$ for lambs under 3 months of age, between 3 and 6 months, 6 and 9 months, and 9 and 12 months of age, respectively.

For goats, El-Hassan El-Abid \& Nikhaila (2009) observed that $21.2 \%$ of pregnancies resulted in abortion, while de Medeiros et al. (2005) reported the highest proportion of mortalities occurring within the first month. Traore \& Wilson (1988) reported that $35 \%$ of all kids died before five months of age in Mali. For both sheep and goats, Tifashe et al. (2017) observed that lambs and kids had higher mortality rates than "young stock" or "adults", however, the specific age range covered by these terms were not defined. Kumar et al. (2016) reported that risk of mortality was highest in kids aged 0-3 months (34.6\%), $>3-6$ months $(25.42 \%)$, and $>6$ months (19.78\%). Turkson (2003) found that for mortalities occurring in kids between birth and 12 months of age, $80.2 \%$ occurred between 0-3 months, with the remaining $19 / 8 \%$ occurring between 4-12 months. In India, Thiruvenkadan \& Karunanithi (2007) longitudinal data from research station records showed that mortality risk was higher in kids from birth to 12 months of age compared to adults older than 12 months. In this cohort, mortality risk was highest around the time of weaning at three months of age.

In Myanmar, a study on village sheep and goats production found that mortality rates were much higher in young animals aged less than 12 months compared to older animals above 12 months (3.0 deaths/100 animals/month and 0.28 deaths/100 animals/month respectively) (Hanks et al., 2018).

Ramachandran et al. (2006) reported on longitudinal data on an experimental crossbred dairy goat herd maintained at a research institute. For goats monitored until 78 months of age (6.5 years), $59 \%$ of all mortalities occurred in the first 3 months of age, and $72 \%$ of mortalities had occurred by 6 months of age. After 6 months of age, mortality risk dropped markedly, and remained low until the goats were $>78$ months of age.

\section{Discussion}

\section{Inconsistencies in definitions}

The inconsistency between definitions of livestock mortality indicators suggests that mortality indicators are not used consistently enough across the industry to be standardised. This is likely due to the predominance of performance indicators based on productivity in HICs, such as daily weight gain, feed conversion ratios, carcass or milk yield or egg production; the irregularity of monitoring in LMICs; and the difficulties in standardising these indicators so that they are applicable across different geographical regions and production systems. However, livestock mortality indicators may become more widely used globally - in HICs due to increasing consumer concerns about animal welfare and the potential utility of mortality indicators in this domain, and in dairy cattle, due to concern about the rising trend in mortality rates seen over the last few decades (Compton et al., 2017; de Vries et al., 2014; Thomsen \& Houe, 2018), and in LMICs due to the inclusion of "Number of animal deaths" in FAO's recommended minimum set of core data within the Global Strategy to improve Agriculture and Rural Statistics (FAO, 2018). In this case, a concerted effort should be made to overcome the difficulties in standardising livestock mortality indicators, as this will facilitate comparisons over time. Several sources of inconsistency that need to be addressed have been identified in this review.

First is the use of mortality risk versus mortality rate. Santman-Berends et al. (2019) compared practical aspects and suitability of mortality rates, where calf days-at-risk was used as the denominator, to mortality risk, where the total number of animals at a specified point in time is used. These authors found that although mortality rate is more accurate, mortality risk was a preferred method of measuring mortality from the scientific, comprehensibility and utilitarian points of view. This finding was supported by the high proportion of studies that reported mortality risk rather than rate. In many cases, method of data capture may not have given authors the degree of precision required to calculate mortality rate. To improve ease of comparison between studies, it may be helpful for studies with access to more detailed data to report both mortality rate and mortality risk, to facilitate comparison with studies with access to less precise data that report mortality risk.

Secondly, based on the studies reviewed here, stakeholders have a greater interest in mortality in young animals. As perinatal and neonatal mortality rates are commonly reported, species-specific definitions for these indicators using age ranges that are appropriate for use across different production systems should be set. For both cattle and goats, more papers defined perinatal mortality as occurring within the first 48 hours of life than other time periods, although variation exists as to whether abortions or stillbirths are included. Due to potential inconsistencies in the detection of abortion or determination of foetal age at abortion under field conditions, the authors propose that perinatal mortality risk be defined for cattle, sheep and goats as animals that are stillborn or die within 48 hours of birth over the total number of still- and liveborn animals. For cattle, sheep and goats, most authors defined the upper age limit of neonatal mortality as one month of age. The authors propose that neonatal mortality risk for all three species include deaths occurring from three to 30 days of age over the total number of animals alive at three days. 
The literature search for the term "pre-weaning mortality" showed that this is a more commonly used indicator for pig production systems than for ruminants. Conceptually, pre-weaning mortality would be a useful indicator in ruminants as it encompasses the age groups with highest risks of mortality. However, due to the high variability in age at weaning between production systems and species, an indicator based on age may be more universally appropriate. For cattle, studies that report pre-weaning mortality rates should, at minimum, specify the age at weaning for the setting of the study. For sheep and goats, reviewed papers seem to concur that the pre-weaning period should extend to 90 days of age. The authors suggest that pre-weaning mortality risk for sheep and goats be defined as the number of liveborn animals that die between birth and 90 days of age over the total number of liveborn animals.

Lastly, for animals past the weaning stage, the age groups for which mortality rates are reported could be standardised. At present, study authors arbitrarily decide on age groupings for reporting or further analysis. In a review attempting to compare magnitude of calf loss across cattle stations in Northern Australia, Chang et al. (2020) identified 42 studies that reported mortality over 13 different time periods. This variation in timelines limited the usefulness of the data, precluding metaanalysis and allowing only summary statistics to be generated. Although the length of studies may vary, if all studies reported on mortality rates for a consistent set of age ranges, this would aid comparisons across data sets and meta-analyses for more powerful results.

\section{Age at mortality}

This review found high agreement between studies on the age groups with the highest incidences of mortality in cattle, sheep and goats, although most evidence was available for cattle. Mortality rates were clearly higher in young animals within the first few months of life, and by six months of age, a large proportion of mortalities in herds and flocks had already occurred. This appears to be a common finding regardless of geographic location or production system and is likely why most studies concentrated on reporting mortality rates for younger animals rather than adults.

While it is commonly reported anecdotally in the literature that the perinatal period or first week of life is the most dangerous period for small ruminants, studies from LMICs also reported higher risk of mortality around the time of weaning, which extends the period where higher mortality risk is observed to 6 months of age. Given the findings in this review, young stock mortality risk, where the number of animals dying within six months of birth over the number of live-born animals could be used as an indicator to cover this vital period. Considering the ability for human infant mortality rates to reflect general population health (Reidpath \& Allotey 2003), the relationship between young stock mortality risk and overall herd or flock health could be an area for further analysis.

\section{Limitations of the study}

There are several limitations to this review. Firstly, the study was limited to one citation database and limited use of Google Scholar. Web of Science was chosen for the breadth of journals indexed within this database and their relevance to livestock science. A large number of search results were generated, however, potentially more articles could have been recovered using a second citation database. Secondly, the study criteria restricting inclusion to peer-reviewed journal articles to ensure a high quality of studies may have limited the amount of data included from LMICs, where there may be language or financial barriers to publishing in peer-reviewed journals, and where operational research from governmental or non-governmental organisations may only be published in the grey literature. Finally, an inadequate number of studies reporting sufficient age distribution of mortality data were identified to conduct a meta-analysis or to disaggregate findings by production system or location.

Practical considerations of mortality rate as an indicator Availability of data. While close to $50 \%$ of the cattle studies included in this review originated from HICs, sheep studies more commonly originated form LMICs, and all included goat studies were from LMICs. In HICs, farmers routinely collect data for the purposes of animal identification, registration, and performance monitoring. Due to the availability of these registries, national-level trends are relatively easy to map. Evidence from LMICs is much scarcer, with studies on mortality usually reporting on small-scale retrospective surveys or using data from institutional research or breeding stations. Lesnoff (2009) found that retrospective survey methods for estimating mortality rates over a 12-month period were fairly reliable for cattle and acceptably reliable for small ruminants, however, care is still required in interpreting survey results due to the large degree of variation within and between years. Season, large shocks, and innovations targeting herd productivity can lead to marked variation, which can affect survey results depending on when they are conducted, and the period(s) covered. Variability was higher for small ruminants than cattle, due to higher reproduction and mortality rates. To limit bias from variability, Lesnoff (2009) recommends that whole herd monitoring over several years, rather than 12-month retrospective surveys, should be employed for data collection and analysis where possible. Currently, this is difficult to achieve in LMICs, where monitoring tools are largely unavailable or unused, national livestock registries do not exist, and the reporting systems and investigation of mortality events are still in nascent form.

Data quality. Countries that maintain national databases for livestock registration appear to have robust and complete records including mortality events. However, the grace period for registration of new animals or the requirement for ear-tagging or other forms of identification to be completed before registration mean that in some cases, mortality within 
the first few days of life may be underreported (Motus et al., 2018; Ortiz-Pelaez et al., 2008; Raboisson et al., 2013; ). A large proportion of young stock mortalities occur within the first seven days of life, particularly in small ruminants, so such unrecorded omissions may be significant.

Data quality may also be an issue in countries that rely on retrospective surveys. Accurate reporting of mortality can be influenced by the skill of the interviewer, and the farmer's ability to accurately recall mortality events (Lesnoff, 2009). Of the studies reviewed, Debnath et al. (1990) were the only authors to discuss the recall accuracy of farmers. These authors reported that farmers were able to reliably recall livestock mortality events, however, the exact ages of animals that died were more difficult to pinpoint. Farmers were more confident in reporting the age group of the animal. In addition to problems of recall, interviewers may encounter reluctance to report mortality, particularly in areas where disease surveillance has previously led to uncompensated control measures to stamp out disease (Gilbert, 2012; Otte et al., 2004).

Cause of mortality. In the reviewed papers, it was rare for mortality rates in themselves to be the sole focus of the study: identifying actual or potential causes of mortality or using modelling to identify risk factors was also an important component. This denotes a major weakness in the use of mortality rates to monitor trends in livestock health; mortality rates only indicate the magnitude of the problem. To be able to make improvements, more information is required for interventions to be able to target to the underlying problems. In areas and/or age groups where the causes for mortality remain consistent over time, trends in mortality rate may be useful to track progress or decline, and to monitor for outbreaks. However, both causes and risk factors may vary widely over geographical and temporal scales. In some regions of the world where livestock mortality rates are consistently high, livestock keepers may be exposed to a variety of shocks year on year, including those related to climate or extreme weather events, political and social stability, and human or animal disease epidemics. In the FAO guidelines for estimating livestock production in LMICs, to monitor herd dynamics and animal health, it is recommended to measure the "number of deaths or disappearance per livestock species and by cause" ${ }^{1}$ rather than just mortality rate (FAO, 2018).

Several of the papers included in this review which presented data spanning multiple years noted that mortality varied greatly from year to year. It was postulated that this was due to environmental stresses such as feed or water shortage, or

\footnotetext{
1 "This indicator measures the total number of heads per livestock species per cause of death or disappearance. Causes of death may be: disease, parasites, accidents, predators, drought, etc. As an option, disappearance per cause (such as strays or theft) may also be estimated, if important in the country" (FAO, 2018)
}

from disease outbreaks. For livestock mortality data to be able to be useful in a timely manner, long term data needs to be collected and accessible. Causes of fluctuations in mortality rates need to be noted, and a "baseline" mortality rate for that region established from the years without external events. This is a similar concept to the "excess deaths" indicator currently being monitored for human mortalities during the COVID-19 pandemic. For livestock, where mortalities follow a seasonal pattern, baseline mortality rates should be established for each season so that if mortality rates rise above baseline at any time through the year, rapid investigation and action is achievable.

\section{Conclusion}

This systematic review finds that although mortality indicators are used to monitor ruminant production systems in both HICs and LMICs, there is a lack of consistency between age groups monitored, time periods covered, and denominators used. It is likely that mortality rate will continue to be used in both HICs and LMICs for the purposes of monitoring animal health or welfare, and comparisons between studies and over time would be aided by the use of standard definitions. The highest proportion of mortalities in cattle, sheep and goats is reported to occur within the first six months of life; therefore, this would be a useful age group over which to measure young stock mortality risk.

However, in itself, mortality rate is an incomplete indicator due to the high level of variability in causes and risk factors. To better understand variations in mortality rate between years, or to target preventative actions, the monitoring of mortality rate should be supplemented with qualitative or quantitative data on likely causes of livestock mortality where possible.

Globally, for the livestock community to increase the utility of data generated and accelerate progress towards improved animal health and welfare, the authors recommend the following actions:

- To improve the interoperability of mortality indicators used for research and monitoring and evaluation, including:

- Improving accuracy in the use of the terms "risk" and "rate". As mortality risk is more widely used and requires less data to calculate, authors should aim to always report mortality risk, supplementing with mortality rate where possible.

- Standardising common indicators such as:

- Perinatal mortality risk, which could be defined in cattle, sheep and goats as including stillbirths and deaths until 48 hours after birth;

- Neonatal mortality risk, which could be defined in cattle, sheep and goats as including deaths occurring between three and 30 days of age; 
- Pre-weaning mortality risk for sheep and goats as death of liveborn animals between birth and 90 days of age; and

- Young stock mortality risk in cattle, sheep and goats as death of liveborn animals between birth and six months of age.

- Selecting appropriate adult age groups for which all researchers can collect data for and report against.

- To support farmers in establishing herd monitoring practices and increasing investment in the creation of national livestock registries.

- To further investment in initiatives that support farmers in establishing and recording the underlying causes of livestock mortality.
Together, these actions will enable farmers to understand the trends and underlying factors causing livestock mortality, and enhance the interoperability and value of data generated from different livestock surveillance and research projects.

\section{Data availability}

All data underlying the results are available as part of the article and no additional source data are required.

\section{Reporting guidelines}

Harvard Dataverse: "Refining livestock mortality indicators: A systematic review PRISMA checklist". https://doi.org/10.7910/ DVN/JJIHJG (Wong, 2021).

Data are available under the terms of the Creative Commons Zero "No rights reserved" data waiver (CC0 1.0 Public domain dedication).
Abdelqader A, Irshaid R, Tabbaa MJ, et al.: Factors influencing Awassi lambs survivorship under fields conditions. Livest Sci. 2017: 199: 1-6. Publisher Full Text

Achard $\mathrm{F}$, Chanono M: Mortalite et performances de reproduction chez le zebu Azaouak a la station de Toukounous, Niger (1986-1992). Revue Elev Med Vet Pays Trop. 1997; 50(4): 325-333.

Reference Source

Aldomy F, Hussein NO, Sawalha L, et al.: A National Survey Of Perinatal Mortality In Sheep And Goats In Jordan. Pak Vet J. 2009; 29(3): 102-106. Reference Source

Al-Khaza'leh J, Mergersa B, Obeidat B: Constraints and risk factors contributing to young stock mortalities in small ruminants in Jordan. Small Rumin Res. 2020; 183: 106033.

Publisher Full Text

Ashley S, Holden S, Bazely P: Livestock in poverty-focused development Crewkerne: Livestock in Development (LID). 1999.

Reference Source

Azzam SM, Kinder JE, Nielsen MK, et al:: Environmental effects on neonatal mortality of beef calves. J Anim Sci. 1993; 71(2): 282-290.

PubMed Abstract | Publisher Full Text

Ba SB, Udo HMJ, Zwart D: Impact of veterinary treatments on goat mortality and offtake in the semi-arid area of Mali. Small Rumin Res. 1996; 19(1):1-8. Publisher Full Text

Bartels CJM, Fakhri AQ, Shams MH, et al.: Livestock mortality and offtake in sheep and goat flocks of livestock owners making use of services offered by paravets in West Afghanistan. Prev Vet Med. 2017; 146: 79-85. PubMed Abstract | Publisher Full Text

Bekele T, Otesile EB, Kasali OB: Influence of passively acquired colostral immunity on neonatal lamb mortality in Ethiopian highland sheep. Small Rumin Res. 1992; 9(3): 209-215.

Publisher Full Text

Binns SH, Cox IJ, Rizvi S, et al.: Risk factors for lamb mortality on UK sheep farms. Prev Vet Med. 2002; 52(3-4): 287-303.

PubMed Abstract | Publisher Full Text

Bleul U: Risk factors and rates of perinatal and postnatal mortality in cattle in Switzerland. Livest Sci. 2011; 135(2-3): 257-264

Publisher Full Text

Brickell JS, McGowan MM, Pfeiffer DU, et al: Mortality in Holstein-Friesian calves and replacement heifers, in relation to body weight and IGF-I concentration, on 19 farms in England. Animal. 2009; 3(8): 1175-1182. PubMed Abstract | Publisher Full Text

Bunter KL, Johnston DJ, Wolcott ML, et al.: Factors associated with calf mortality in tropically adapted beef breeds managed in extensive Australian production systems. Anim Prod Sci. 2014; 54(1): 25-36. Publisher Full Text

Busato A, Steiner L, Tontis A, et al:: [Frequency and etiology of calf losses and calf diseases in cow-calf farms. I. Methods of data collection, calf mortality, and calf morbidity]. Dtsch Tierarztl Wochenschr. 1997; 104(4): 131-135. PubMed Abstract

CDC: Lesson 3: Measures of risk, Section 3: Mortality frequency measures, Mortality rate. Atlanta: Centers for Disease Control and Prevention. 2012; Accessed 23 May 2020

Reference Source

Chang AZ, Swain DL, Trotter MG: Calf loss in northern Australia: a systematic review. RangelJ. 2020; 42(1): 9-26.

Publisher Full Text

Chikagwa-Malunga SK, Banda JW: Productivity and survival ability of goats in smallholder crop/livestock farming systems in Malawi. Livestock Research for Rural Development. 2006; 18(1).

Reference Source

Compton CWR, Heur C, Thomsen PT, et al.: Invited review: A systematic literature review and meta-analysis of mortality and culling in dairy cattle. J Dairy Sci. 2017; 100(1): 1-16.

PubMed Abstract | Publisher Full Text

Cuttance E, Laven R: Perinatal mortality risk factors in dairy calves. Vet J 2019; 253: 105394.

PubMed Abstract | Publisher Full Text

de Medeiros JM, Tabosa LM, Simoes SVD, et al: Perinatal mortality in kids in the semiarid region of Paraiba, Brazil. Pesquisa Veterinaria Brasileira. 2005; 25(4): 201-206.

Publisher Full Text

de Vries M, Bokkers EAM, van Schaik G, et al: Exploring the value of routinely collected herd data for estimating dairy cattle welfare. J Dairy Sci. 2014; 97(2): 715-730.

PubMed Abstract | Publisher Full Text

Debnath NC, Sil BK, Selim SA, et al.: A retrospective study of calf mortality and morbidity on smallholder traditional farms in Bangladesh. Prev Vet

Med. 1990; 9(1): 1-7.

Publisher Full Text

Debnath N, Taimur MJFA, Saha AK, et al.: A retrospective study of calf losses on the Central Dairy Cattle Breeding Station in Bangladesh. Prev Vet Med.

1995; 24(1): 43-53.

Publisher Full Text

Deribe G, Abebe G, Tegegne A: Non-genetic factors influencing reproductive traits and pre-weaning mortality of lambs and kids under smallholder management, Southern Ethiopia. J Anim Plant Sci. 2014; 24(2): 413-417. Reference Source

Dhakal K, Maltecca C, Cassady JP, et al.: Calf birth weight, gestation length, calving ease, and neonatal calf mortality in Holstein, Jersey, and crossbred cows in a pasture system. J Dairy Sci. 2013; 96(1): 690-698.

PubMed Abstract | Publisher Full Text

El-Hassan El-Abid K, Nikhaila AMA: A study on some factors affecting 
mortality rates in Sudanese Nubian kids. Int J Dairy Sci. 2009; 4(2): 74-79. Publisher Full Text

Erdogan HM, Unver A, Citil M, et al.: Dairy farming in Kars district, Turkey: III. Neonatal calf health. Turk J Vet Anim Sci. 2009; 33(3): 185-192.

Publisher Full Text

FAO: The State of Food and Agriculture - Livestock in the Balance. Rome: Food and Agriculture Organization of the United Nations (FAO). 2009. Reference Source

FAO: Guidelines on methods for estimating livestock production and productivity. Publication prepared in the framework of the Global Strategy to improve Agricultural and Rural Statistics. Rome: FAO. 2018. Accessed 5 June 2020.

Reference Source

Fentie T: Assessment of young stock mortality in major livestock production systems of Ethiopia. February 2016 Revised Research Report. Washington D. C.: Feed the Future. 2016.

Reference Source

Fentie T, Guta S, Mekonen G, et al:: Assessment of major causes of calf mortality in urban and periurban dairy production system of Ethiopia. Vet Med Int. 2020; 2020: 3075429.

PubMed Abstract | Publisher Full Text | Free Full Text

Fragkou IA, Mavrogianni VS, Fthenakis GC: Diagnostic investigation of cases of deaths of newborn lambs. Small Rumin Res. 2010; 92(1-3): 41-44. Publisher Full Text

Fuerst-Waltl B, Fuerst C: Mortality in Austrian dual purpose Fleckvieh calves and heifers. Livest Sci. 2010; 132(1-3): 80-86.

Publisher Full Text

Fuerst-Waltl B, Sørensen MK: Genetic analysis of calf and heifer losses in Danish Holstein. J Dairy Sci. 2010; 93(11): 5436-5442.

PubMed Abstract | Publisher Full Text

Ganaba R, Bengaly Z, Ouattara L: Calf morbidity, mortality and parasite prevalences in the cotton zone of Burkina Faso. Prev Vet Med. 2002.55: 209-216.

PubMed Abstract | Publisher Full Text

Gardner IA, Hird DW, Utterback WW, et al.: Mortality, morbidity, case-fatality, and culling rates for California dairy cattle as evaluated by the National Animal Health Monitoring System, 1986-87. Preventative Veterinary Medicine. 1990; 8(2-3): 157-170.

Publisher Full Text

Gascoigne E, Bazeley K, Lovatt F: Can farmers reliably perform neonatal lamb post-mortems and what are the perceived obstacles to influencing lamb mortality? Small Rumin Res. 2017; 151: 36-44.

Publisher Full Text

Gilbert N: Cost of human-animal disease greatest for world's poor. Nature News. 2012; Accessed 19 August 2020.

Reference Source

Gitau GK, McDermott JJ, Waltner-Toews D, et al.: Factors influencing calf morbidity and mortality in smallholder dairy farms in Kiambu District of Kenya. Prev Vet Med. 1994; 21(2): 167-177.

Publisher Full Text

Gokce E, Erdogan HM: An epidemiological study on neonatal lamb health. Kafkas Universitesi Veteriner Fakultesi Dergisi. 2009; 15(2): 225-236.

Reference Source

Gokce E, Kirmizigul AH, Erdogan HM, et al: : Risk factors associated with passive immunity, health, birth weight and growth performance in lambs: 1. Effect of parity, dam's health, birth weight, gender, type of birth and lambing season on morbidity and mortality. Kafkas Universitesi Vetine Fakultesi Dergisi. 2013; 19: A153-A160.

Publisher Full Text

Gowane GR, Swarnkar CP, Prince LLL, et al.: Genetic parameters for neonatal mortality in lambs at semi-arid region of Rajasthan India. Livest Sci. 2018 210: 85-92.

Publisher Full Text

Gulliksen SM, Lie KI, Løken T, et al.: Calf mortality in Norwegian dairy herds. J Dairy Sci. 2009; 92(6): 2782-2795.

PubMed Abstract | Publisher Full Text

Gundelach Y, Essmeyer K, Teltscher MK, et al.: Risk factors for perinatal mortality in dairy cattle: Cow and foetal factors, calving process.

Theiogenology. 2009; 71(6): 901-909.

PubMed Abstract | Publisher Full Text

Hanks JE, Glanville EJ, Phyu E, et al.: Using longitudinal syndromic surveillance to describe small ruminant health in village production systems in Myanmar. Prev Vet Med. 2018: 160: 47-53.

PubMed Abstract | Publisher Full Text

Herrero M, Grace D, Njuki J, et al:: The roles of livestock in developing

countries. Animal. 2013; 7(Suppl 1): 3-18.

PubMed Abstract | Publisher Full Text

Holmoy IH, Waage S: Time trends and epidemiological patterns of perinatal lamb mortality in Norway. Acta Vet Scand. 2015; 57: 65.

PubMed Abstract | Publisher Full Text | Free Full Text

Holmoy IH, Kielland C, Stubsjøen SM, et al.: Housing conditions and

management practices associated with neonatal lamb mortality in sheep

flocks in Norway. Prev Vet Med. 2012; 107(3-4): 231-241.

PubMed Abstract | Publisher Full Text
Holmøy IH, Waage S, Granquist EG, et al.: Early neonatal lamb mortality: postmortem findings. Animal. 2017; 11(2): 295-305.

PubMed Abstract | Publisher Full Text

Hoy $D$, Brooks $P$, Woolf $A$, et al: Assessing risk of bias in prevalence studies: modification of an existing tool and evidence of interrater agreement.

Clin Epidemiol. 2012; 65(9): 934-939.

PubMed Abstract | Publisher Full Text

Hyde RM, Green MJ, Sherwin VE, et al.: Quantitative analysis of calf mortality in Great Britain. J Dairy Sci. 2020; 103(3): 2615-2623.

PubMed Abstract | Publisher Full Text

Khan A, Sultan MA, Jalvi MA, et al.: Risk factors of lamb mortality in Pakistan. Anim Res. 2006; 55(4): 301-311.

Publisher Full Text

Knopf L, Komoin-Oka C, Betschart B, et al.: Production and health parameters of N'Dama village cattle in relation to parasitism in the Guinea Savannah of Cote d'Ivoire. 2004

Reference Source

Kudi AC, Umoh JU, Eduvie LO, et al.: Relative survival of calves in 16 traditionally managed herds in Bauchi, Nigeria. Prev Vet Med. 1998; 36(4): 307-312.

PubMed Abstract | Publisher Full Text

Kumar V, Singh BP, Dutt T: Production performance of goat in field condition: A survey in semi-arid zone of Uttar Pradesh, India. Indian J Anim Sci. 2016; 86(10): 1187-1191.

Lesnoff M: Reliability of a twelve-month retrospective survey method for estimating parturition and mortality rates in a traditional African livestock farming system. Revue Élev Méd vét Pays tro. 2009; 62(1): 49-57. Reference Source

Mahendran SA, Booth R, Beekhuis L, et al.: Assessing the effects of weekly preweaning health scores on dairy calf mortality and productivity parameters: cohort study. Vet Rec. 2017; 181(8): 196

PubMed Abstract | Publisher Full Tex

Mandal A, Prasad H, Kumar A, et al:: Factors associated with lamb mortalities in Muzaffarnagari sheep. Small Rumin Res. 2007: 71(1-3): 273-279. Publisher Full Text

Mee JF, Berry DP, Cromie AR: Prevalence of, and risk factors associated with, perinatal calf mortality in pasture-based Holstein-Friesian cows. Animal. 2008; 2(4): 613-620.

PubMed Abstract | Publisher Full Text

Mellado M, Lopez E, Veliz FG, et al.: Factors associated with neonatal dairy calf mortality in a hot-arid environment. Livestock Science. 2014: 159:149155

Publisher Full Text

Mellado M, Macias U, Avendano L, et al.: Growth and pre-weaning mortality of Katahdin lamb crosses. Revista Colombiana de Ciencias Pecuarias. 2016; 29(4): 288-295.

Publisher Full Text

Menzies FD, Bryson DG, McCallion T, et al.: Mortality in cattle up to two years old in Northern Ireland during 1992. Vet Rec. 1996; 138(25): 618-622. PubMed Abstract | Publisher Full Text

Mock T, Mee JF, Dettwiler M, et al.: Evaluation of an investigative model in dairy herds with high calf perinatal mortality rates in Switzerland. Theriogenology. 2020; 148: 48-59.

PubMed Abstract | Publisher Full Text

Moher D, Liberati A, Tetzlaff J, et al.: Preferred Reporting Items for Systematic Reviews and Meta-Analyses: The PRISMA Statement. PLoS Med. 2009; 6(7): e1000097.

PubMed Abstract | Publisher Full Text | Free Full Text

Motus $\mathrm{K}$, Reimus $\mathrm{K}$, Orro $\mathrm{T}$, et al: On-farm mortality, causes and risk factors in Estonian beef cow-calf herds. Prev Vet Med. 2017; 139(Pt A): 10-19. PubMed Abstract | Publisher Full Text

Motus K, Viltrop A, Emanuelson U: Reasons and risk factors for beef calf and youngstock on-farm mortality in extensive cow-calf herds. Animal. 2018; 12(9): 1958-1966.

PubMed Abstract | Publisher Full Text

Norberg E, Pryce JE, Pedersen J: Short communication: A genetic study of mortality in Danish Jersey heifer calves. J Dairy Sci. 2013; 96(6): 4026-4030. PubMed Abstract | Publisher Full Text

Ortiz-Pelaez A, Pritchard DG, Pfeiffer DU, et al.: Calf mortality as a welfare indicator on British cattle farms. Vet J. 2008; 176(2): 177-181.

PubMed Abstract | Publisher Full Text

Otte MJ, Nugent R, McLeod A: Transboundary animal diseases: Assessment of socio-economic impacts and institutional responses. Livestock Policy Discussion Paper No. 9. Rome: FAO Livestock Information and Policy Branch, 2004; Accessed 19 August 2020.

Reference Source

Pannwitz G: Standardized analysis of German cattle mortality using national register data. Prev Vet Med. 2015; 118(4): 260-270.

PubMed Abstract | Publisher Full Text

Peeler EJ, Wanyangu SW: Infectious causes of small ruminant mortality in Kenya: A review. Small Rumin Res. 1998; 29(1): 1-11.

Publisher Full Text

Perry BD, Grace $D$, Sones K: Current drivers and future directions of global livestock disease dynamics. Proc Natl Acad Sci U S A. 2013; 110(52): 
20871-20877.

PubMed Abstract | Publisher Full Text | Free Full Text

Perry BD, Randolph TF, McDermott JJ, et al.: Investing in animal health research to alleviate poverty. Nairobi: International Livestock Research Institute (ILRI), 2002.

Reference Source

Prasad S, Ramachandran N, Raju S: Mortality patterns in dairy animals under organized herd management conditions at Karnal, India. Trop Anim Health Prod. 2004; 36(7): 645-654.

PubMed Abstract | Publisher Full Text

Pritchard T, Coffey M, Mrode R, et al.: Understanding the genetics of survival in dairy cows. J Dairy Sci. 2013; 96(5): 3296-3309.

PubMed Abstract | Publisher Full Text

Raboisson D, Delor F, Cahuzac E, et al.: Perinatal, neonatal, and rearing period mortality of dairy calves and replacement heifers in France. J Dairy Sci. 2013: 96(5): 2913-2924.

PubMed Abstract | Publisher Full Text

Ramachandran N, Prasad S, Raju S: Mortality pattern in crossbred dairy

goats in semiarid India. Indian J Anim Sci. 2006: 76(10): 843-846.

Reference Source

Rattner D, Riviere J, Bearman JE: Factors affecting abortion, stillbirth and kid mortality in the goat and yaez (goat x ibex). Small Rumin Res. 1994; 13(1): 33-40.

Reference Source

Reidpath DD, Allotey P: Infant mortality rate as an indicator of population health. J Epidemiol Community Health. 2003; 57(5): 344-346.

PubMed Abstract | Publisher Full Text | Free Full Text

Reimus K, Alvåsen K, Emanuelson U, et al.: Herd-level risk factors for cow and calf on-farm mortality in Estonian dairy herds. Acta Vet Scand. 2020; 62(1): 15. PubMed Abstract | Publisher Full Text | Free Full Text

Reimus $K$, Orro $T$, Emanuelson $U$, et al: Reasons and risk factors for on-farm mortality in Estonian dairy herds. Livest Sci 2017; 198: 1-9.

Publisher Full Text

Ring SC, McCarthy J, Kelleher MM, et al.: Risk factors associated with animal mortality in pasture-based, seasonal-calving dairy and beef herds. I Anim Sci. 2018: 96(1): 35-55.

PubMed Abstract | Publisher Full Text | Free Full Text

Sallam AM: Risk factors and genetic analysis of pre-weaning mortality in Barki lambs. Livest Sci. 2019; 230(7): 103818.

Publisher Full Text

Salmon GR, MacLeod M, Claxton JR, et al.: Exploring the landscape of livestock 'Facts'. Glob Food Sec. 2020; 25(1): 100329.

PubMed Abstract | Publisher Full Text | Free Full Text

Santman-Berends I, Schukken YH, van Schaik G: Quantifying calf mortality on dairy farms: Challenges and solutions. J Dairy Sci. 2019; 102(7): 6404-6417. PubMed Abstract | Publisher Full Text

Schreuder BEC, Moll HAJ, Noorman N, et al.: A benefit-cost analysis of veterinary interventions in Afghanistan based on a livestock mortality study. Prev Vet Med. 1996; 26(3-4): 303-314.

Publisher Full Text

Selvan AS, Tantia MS, Ravi Kumar D, et al.: Factors influencing calf mortality in zebu and crossbred cattle reared under subtropical agroclimatic conditions. Indian J Anim Sci. 2019; 89(3): 80-85.

Reference Source

Seppa-Lassila L, Sarjokari K, Hovinen M, et al.: Management factors associated with mortality of dairy calves in Finland: A cross sectional study. Vet J. 2016; 216: 164-167.

PubMed Abstract | Publisher Full Text

Shaw APM, Rushton J, Roth F, et al.: DALYs, dollars and dogs: how best to analyse the economics of controlling zoonoses. Rev Sci Tech. 2017: 36(1): 147-161.

PubMed Abstract

Slavik P. ILlek J, Brix M, et al: Health Status of Beef Cows and their Calves in the Czech Republic. Acta Veterinaria Brno. 2009; 78(1): 47-56. Publisher Full Text

Svensson C, Linder A, Olsson S-O: Mortality in Swedish dairy calves and replacement heifers. J Dairy Sci. 2006; 89(12): 4769-4777.

PubMed Abstract | Publisher Full Text

Swai EA, Karimuribo ED, Kambarage DM, et al.: A longitudinal study on morbidity and mortality in youngstock smallholder dairy cattle with special reference to tick borne infections in Tanga region, Tanzania. Vet Parasitol. 2009; 160(1-2): 34-42.

PubMed Abstract | Publisher Full Text

Swai ES, Karimuribo ED, Kambarage DM: Risk factors for smallholder dairy cattle mortality in Tanzania. J S Afr Vet Assoc. 2010; 81(4): 241-246.

PubMed Abstract | Publisher Full Text
Thiruvenkadan AK, Karunanithi K: Mortality and replacement rate of Tellicherry and its crossbred goats in Tamil Nadu. Indian J Anim Sci. 2007; 77(7): 590-594.

Reference Source

Thomsen PT, Houe H: Cow mortality as an indicator of animal welfare in dairy herds. Res Vet Sci. 2018; 119: 239-243.

PubMed Abstract | Publisher Full Text

Thrusfield M, Christley R: Describing disease occurrence: Mortality. In: Thrusfield, M. \& Christley, R. Veterinary epidemiology. Oxford: Wiley Blackwell. 2018; 72-79.

Thumbi SM, Bronsvoort MB, Kiara $\mathrm{H}$, et al:: Mortality in East African shorthorn zebu cattle under one year: predictors of infectious-disease mortality. BMC Vet Res. 2013; 9: 175

PubMed Abstract | Publisher Full Text | Free Full Text

Tifashe M, Hassan A, Herago T, et al:: Analysis of morbidity and mortality of sheet and goat in Wolaita Soddo Zuria District, Southern Ethiopia. Glob Vet. 2017; 18(3): 168-177.

Reference Source

Traore A, Wilson RT: Livestock production in central Mali: Environmental and pathological factors affecting morbidity and mortality of ruminants in the agro-pastoral system. Preventative Veterinary Medicine. 1988; 6(1): 63-75. Publisher Full Text

Turkson PK: Lamb and kid mortality in village flocks in the coastal savanna zone of Ghana. Trop Anim Health Prod. 2003. 35(6): 477-490.

PubMed Abstract | Publisher Full Text

Uetake K: Newborn calf welfare: A review focusing on mortality rates. Anim Sci J. 2013; 84(2): 101-105.

PubMed Abstract | Publisher Full Text | Free Full Text

UNSD: E-Handbook on SDG indicators. New York: United Nations Statistics Division. 2020a; Accessed 28 April 2020.

Reference Source

UNSD: SDG Indicators - Metadata repository. New York: United Nations Statistics Division. 2020b. Accessed 28 April 2020

Reference Source

Upadhyay A, Sadana DK, Gupta AK, et al.: Influence of non-genetic factors on disposal pattern of Sahiwal cattle under an organized farm. Indian J Anim Res. 2014: 84(11): 1206-1210.

Reference Source

Upadhyay VK, Mehla RK, Gupta AK, et al.: Demographic parameters and disposal pattern in Sahiwal cattle herd. Indian J Anim Sci. 2017; 87(4): 437-442. Reference Source

Vatankhah M, Talebi MA: Genetic and Non-genetic Factors Affecting Mortality in Lori-Bakhtiari Lambs. Asian-Australas J Anim Sci. 2009; 22(4): 459-464.

Publisher Full Text

Voigt K, Frohnmayer S, Strobel H, et al.: Time pattern and causes of lamb mortality on commercial sheep farms in Southern Germany operating conservation grazing and non-seasonal production systems - a field study. Berl Munch Tierarztl Wochenschr. 2019: 132(3-4): 156-165.

Publisher Full Text

Voljc M, Cepon M, Malorvh S, et al.: Risk factors and mortality rate of calves in the first month of life in Slovenian Holstein Friesian population. Journa of Central European Agriculture. 2019; 20(1): 25-30.

Publisher Full Text

WHO: Maternal, newborn, child and adolescent health and ageing. World Health Organization. 2021. Accessed 3 February 2021.

Reference

Wittum TE, Salman MD, King ME, et al.: Individual animal and maternal risk factors for morbidity and mortality of neonatal beef-calves in Colorado, USA. Prev Vet Med. 1994; 19(1): 1-13.

Publisher Full Text

Wong J: "Refining livestock mortality indicators: A systematic review PRISMA checklist", Harvard Dataverse, V1; PRISMA 2009 checklist - Livestock mortality review.doc [fileName]. 2021.

http://www.doi.org/10.7910/DVN/JJIHJG

World Bank Data Team: New country classifications by income level: 2019 - 2020. Washington D. C.: The World Bank Group. 2019. Accessed 29 April 2020. Reference Source

Wymann MN, Bonfoh B, Schelling B, et al: Calf mortality rate and cause of death under different herd management systems in peri-urban Bamako, Mali. Livest Sci. 2006; 100(2-3): 169-178.

Publisher Full Text

Zhang $\mathrm{H}$, Wang $\mathrm{Y}$, Chang $\mathrm{Y}$, et al.: Mortality-culling rates of dairy calves and replacement heifers and its risk factors in Holstein cattle. Animals (Basel). 2019; 9 (10): 730.

PubMed Abstract | Publisher Full Text | Free Full Text 


\section{Open Peer Review}

\section{Current Peer Review Status:}

\section{Version 1}

Reviewer Report 17 August 2021

https://doi.org/10.21956/gatesopenres.14456.r30999

(C) 2021 Calderón Díaz J et al. This is an open access peer review report distributed under the terms of the Creative Commons Attribution License, which permits unrestricted use, distribution, and reproduction in any medium, provided the original work is properly cited.

\section{Julia Adriana Calderón Díaz}

Pig Development Department, Teagasc Animal and Grassland Research and Innovation Centre, Fermoy, Ireland

\section{Martyna Lagoda}

Pig Development Department, Teagasc Animal and Grassland Research and Innovation Centre, Fermoy, Ireland

We would like to congratulate the authors in preparing a very comprehensive and well structured literature review. The article tries, for the first time, to harmonise definitions for mortality in cattle and small ruminants which could be used as a first step to develop and/or improve animal health surveillance programs mostly in low-middle income countries. Livestock mortality negatively affects the livelihoods of those involved in animal production, and addressing the issue identified in this review thus has the potential to improve monitoring, as well as the development of practical solutions to ameliorate increasing livestock mortality. The topic of this review is therefore of great value.

The authors give a clear overview of the background information needed to understand the rationale for this systematic review, and also provide an easy to follow outline of the literature search technique used to conduct this review. Throughout the article, the authors point out to the inconsistency in the use of mortality indicator definitions in the existing literature and some of the main challenges to set standard definitions, and indicator variables across species, production systems and geographical areas.

Lots of very useful information on the reviewed articles is concisely presented in the tables used. If we can recommend something in the article, that would be the information presented in the figures. We found the line patterns used to represent the information from various studies in Figure 3 quite difficult to distinguish. If possible, we would recommend that the authors try to make this figure clearer. In addition, the word "includes" within the caption of Figure 3 should be removed.

Finally, based on the information deduced by the authors from the articles which they reviewed, 
the recommendations for future work and potential terms to be used when discussing livestock mortality seem very well formed and are likely to be of value to future authors.

Are the rationale for, and objectives of, the Systematic Review clearly stated? Yes

Are sufficient details of the methods and analysis provided to allow replication by others? Yes

Is the statistical analysis and its interpretation appropriate? Yes

Are the conclusions drawn adequately supported by the results presented in the review? Yes

Competing Interests: No competing interests were disclosed.

Reviewer Expertise: Livestock production; Animal welfare, Whole farm modelling; Stochastic bioeconomic modelling; Bio-security

We confirm that we have read this submission and believe that we have an appropriate level of expertise to confirm that it is of an acceptable scientific standard.

Reviewer Report 11 August 2021

https://doi.org/10.21956/gatesopenres.14456.r30998

(c) 2021 Jaja I. This is an open access peer review report distributed under the terms of the Creative Commons Attribution License, which permits unrestricted use, distribution, and reproduction in any medium, provided the original work is properly cited.

Ishmael Festus Jaja

Department of Livestock and Pasture Sciences, Risk and Vulnerability Science Centre, University of Fort Hare, Alice, South Africa

General comments:

The manuscript "Refining livestock mortality indicators: a systematic review", presents a compelling quantitative description of livestock mortality indicators vis-a-vis age delineation. Based on its finding, the authors proposed using mortality risk to improve the interoperability of livestock mortality indicators. They further suggested the standardizing common indicators such as perinatal, preweaning, neonatal and young stock mortality risk. The manuscript is well written and easy to understand. I found a few typographical errors, and I also suggest the authors reading the draft repeatedly to correct such errors.

\section{Comments:}


"An overview of the criteria used to identify literature relating to the two purposes of this review is presented in in Table 4" - Delete "in", it was typed twice.

The authors stated, "Given the scoping nature of this section of the review, studies were not individually assessed for bias" - My opinion of the paper, given the risk of bias and its nonassessment, the authors could better call this paper a scoping review.

\section{Are the rationale for, and objectives of, the Systematic Review clearly stated?}

Yes

Are sufficient details of the methods and analysis provided to allow replication by others? Yes

Is the statistical analysis and its interpretation appropriate?

Partly

Are the conclusions drawn adequately supported by the results presented in the review? Yes

Competing Interests: No competing interests were disclosed.

Reviewer Expertise: Ishmael Festus Jaja, is a veterinarian in the Department of Livestock and Pasture Science, University of Fort Hare, Alice, South Africa. He obtained his DVM from the University of Nigeria, Nsukka, MSc and PhD from the University of Fort Hare, South Africa. He specializes in Veterinary public health, food safety, especially foodborne pathogen, and antimicrobial resistance.

I confirm that I have read this submission and believe that I have an appropriate level of expertise to confirm that it is of an acceptable scientific standard.

Reviewer Report 28 July 2021

https://doi.org/10.21956/gatesopenres.14456.r30819

(C) 2021 Cook A. This is an open access peer review report distributed under the terms of the Creative Commons Attribution License, which permits unrestricted use, distribution, and reproduction in any medium, provided the original work is properly cited.

\section{Alasdair J.C. Cook}

Department of Veterinary Epidemiology and Public Health, School of Veterinary Medicine, University of Surrey, Guildford, UK

This review addresses an important issue with respect to assessment of the health and productivity of livestock - the use of mortality data. The authors conducted a formal literature 
review and identified 85 articles for data extraction. Most of these related to cattle. Useful tables are presented showing the range of definitions related to mortality by species and age group, emphasising the lack of consistency that is seen. Data were summarised to present useful cumulative mortality curves for cattle; the standard deviation bars are wide illustrating the great diversity in mortality within age groups and between countries. The authors recommend terminology related to mortality rate and risk is adhered to by authors and also stress the importance of defining the age groups to which such measures are applied. They also emphasise that a crude measure of mortality alone is of limited value and that cause-specific measures and/or additional qualitative or quantitative information should be provided.

This is an excellent and authoritative article; it should be widely used as a reference by future authors concerned with reporting livestock mortality and also be useful as a guide to reviewers of such articles.

Are the rationale for, and objectives of, the Systematic Review clearly stated? Yes

Are sufficient details of the methods and analysis provided to allow replication by others? Yes

Is the statistical analysis and its interpretation appropriate?

Yes

Are the conclusions drawn adequately supported by the results presented in the review? Yes

Competing Interests: No competing interests were disclosed.

Reviewer Expertise: I am a veterinary epidemiologist with research interests in infectious diseases and zoonoses, one health, the surveillance of livestock disease and in the health and productivity of livestock in production systems in developed countries and LMICs

I confirm that I have read this submission and believe that I have an appropriate level of expertise to confirm that it is of an acceptable scientific standard. 